Saint Louis University School of Law

Scholarship Commons

All Faculty Scholarship

2002

Disability, Doctors and Dollars: Distinguishing the Three Faces of Reasonable Accommodation

Elizabeth Pendo

Follow this and additional works at: https://scholarship.law.slu.edu/faculty

Part of the Disability Law Commons, and the Health Law and Policy Commons 


\title{
Disability, Doctors and Dollars: Distinguishing the Three Faces of Reasonable Accommodation
}

\author{
Elizabeth A. Pendo*
}

Despite a decade of litigation, there is no consistent understanding of the reasonable accommodation requirement of Title I of the ADA. Indeed, there are three inconsistent distributive outcomes that appear to comport with the reasonable accommodation requirement: cost-shifting, cost-sharing, and costavoidance.

One reason for such inconsistent outcomes is a failure to develop a coherent and consistent theory of disability. Because disability has been and continues to be medicalized, this Article takes a fresh look at the medical literature on health, illness, and disability. It recommends the use of the experiential health model over the currently accepted functional health model to understand disability in the context of the ADA because it captures the contextual, socially-constructed, and political nature of disability.

A second, related reason for inconsistent outcomes is an ambivalent attitude toward the costs of antidiscrimination law, often expressed as a tension between efficiency and rights. This Article examines disability-based discrimination in the workplace in this context, revealing the underlying tension between disability discrimination as a civil rights issue, and the view of disability discrimination as a social safety net issue.

Assistant Professor, St. Thomas University School of Law; B.A. 1990, University of California, Los Angeles; J.D. 1993, Boalt Hall School of Law, University of California, Berkeley. I am grateful to St. Thomas University School of Law for research support and for the opportunity to present and/or discuss my work in progress at the following conferences: The 2001 Oxford Round Table, focusing on employment discrimination; the 2001 AALS Annual Meeting, Section on Women in Legal Education; the 2000 ADA Conference at the Ohio State University College of Law; and to the Southern Florida Working Group on Bioethics and Health Law. I am also grateful to Angie Valle-Peters and Maria Valle-Peters for their excellent research assistance. 
Using a theory of disability informed by an experiential definition of health and the distributive analysis to evaluate the three distributive outcomes demonstrates that, although flawed, cost-shifting is the best outcome because it embodies an experiential-social model of disability and the potential for both socioeconomic and political reconstruction.

\section{TABLE OF CONTENTS}

I. The Three FACES of ReASONABle ACCOMMODATION ................... 1178

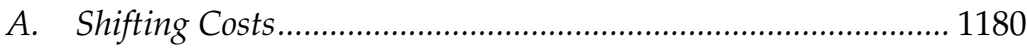

B. Sharing Costs ...................................................................... 1184

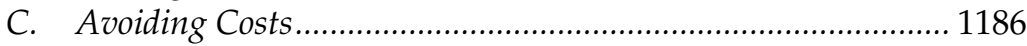

II. Defining Disability: An Alternative Medical Model.......... 1191

A. The Traditional Medical Model of Disability............................. 1192

1. The History: A Progression of Models of Disability ... 1192

2. The Present: Centrality of a Traditional Medical

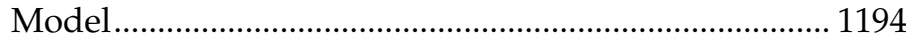

B. Re-examining the Medical Literature: Two Views of Health.... 1196

1. Functional Health and the Traditional Medical

Model of Disability

2. Experiential Health and the Social Model of

Disability

III. Debating Distribution: Reasonable Accommodation AND

COSTS.

A. The Language of Efficiency and the ADA................................ 1204

1. Neoclassical Economic Model.......................................... 1204

2. Critique of the Neoclassical Economic Model .............. 1205

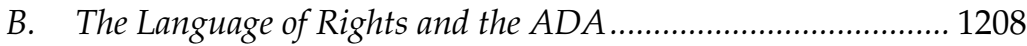

1. Negative and Positive Rights ......................................... 1209

2. Critique of the Negative-Positive Dichotomy ………..... 1211

IV. BACK TO THE THREE FACES OF REASONABLE ACCOMMODATION.. 1213

A. Cost Avoidance is an Unwelcome Return to the Past................ 1213

1. A Strong Medical-Functional Model of Disability ....... 1214

2. Special Distributions for Unsuitable Workers ............... 1215

B. Cost-Sharing is an Uncertain Bargain ...................................... 1219

1. A Weak Medical-Functional Model of Disability .......... 1219

2. Bargaining for Benefits.................................................... 1219

C. Though Flawed, Cost Shifting is the Best Outcome................... 1221

1. A Potentially Strong Experiential-Social Model of Disability 1221

2. An Opportunity for Redistribution and Social

Reconstruction 1223 
Despite intense interest in the Americans with Disabilities Act of $1990^{1}$ (the "ADA") for over a decade, there is no consistent understanding of the reasonable accommodation requirement of Title I, the employment title. Indeed, at least three distinct distributive outcomes appear to comport with the requirements of the ADA. An employee with a disability $^{2}$ who is willing and able to work within the meaning of the statute may: 1 ) receive reasonable accommodation as defined by law; 2 ) privately bargain for some level of accommodation, as defined by the bargaining parties; or 3) leave the workplace with employer-sponsored disability leave benefits. These inconsistencies point to more fundamental questions - what does it mean to have a disability, and what, if anything, is society obligated to do for people with disabilities? ${ }^{3}$

The aim of this Article is to begin to build answers to these questions. Part I outlines the reasonable accommodation requirement of Title I of the ADA and identifies three inconsistent distributive outcomes pursuant to the ADA's requirements: 1) cost shifting from the employee to the employer, based on the ADA's requirement that employers make reasonable accommodation for qualified individuals with disabilities; 2) cost sharing between the employee and the employer, based on observations that the ADA has actually created a zone of bargaining rather than shifting the costs to the employer, and 3) cost avoidance, which occurs when the operation of another federal law, The Employee Retirement Income Security Act of $1974^{4}$ ("ERISA"), enables the employer to avoid the requirement of reasonable accommodation. Part II re-examines the medical literature for support in developing a coherent theory of disability that is currently lacking, and identifies the experiential health model as particularly valuable because it captures the

42 U.S.C. §§ 12101-12213 (1994).

2 This Article uses the term "individual with a disability," rather than terms such as "disabled person" or "handicapped person," which tend to define the individual only in terms of the disability. For a discussion of the social meaning of common terminology used to identify or describe people with disabilities, see generally Paul K. Longmore, $A$ Note on Language and the Social Identity of Disabled People, 28 AM. BEHAV. SCIENTIST 419 (1985); Tanya Titchkosky, Disability: A Rose By Any Other Name? "People First" Language in Canadian Society, 38 CAN. REV. SOC. \& ANTHROPOLOGY 125 (2001).

3 See Richard K. Scotch, Models of Disability and the Americans with Disabilities Act, 21 BERKELEY J. EMP. \& LAB. L. 213, 214-15, 213-222 (2000) (defining a disability as limitation on what people are assumed to be able to do without assistance).

${ }_{4} 29$ U.S.C. $\S 1001-1461$ (1994). 
contextual, socially-constructed, and political nature of disability. Part III explores the ambivalent attitude toward the costs of antidiscrimination law and disability-based discrimination in the workplace, in particular revealing a "deep tension between the view of disability discrimination as a civil rights problem, and the view of disability discrimination as a social safety net issue." ${ }^{\prime 5}$ Finally, Part IV uses a theory of disability informed by an experiential definition of health as well as the distributive analysis to evaluate the three distributive outcomes and demonstrates that, although flawed, costshifting is the best outcome.

\section{THE THREE FACES OF REASONABLE ACCOMMODATION}

The ADA was enacted to "provide strong, consistent, [and] enforceable standards [for] ending discrimination against individuals with disabilities," and to bring such individuals into the economic and social mainstream of American life. ${ }^{6}$ In an attempt to remedy the widespread problem of discrimination against people with disabilities, Congress used its power under the Commerce Clause and the Fourteenth Amendment and prohibited discrimination "across the entire vista of modern society: discrimination is prohibited in employment, public services, public transportation, public accommodations and public services operated by private entities and telecommunications." ${ }^{7}$ Structurally and substantively, the ADA is based on Title VII of the Civil Rights Act of 1964 ("Title VII"), which prohibits discrimination on the basis of race, national origin, sex, and religion. However, the ADA faces unique challenges to the implementation of civil rights for people with disabilities not faced by Title VII, or prior federal statutes aimed at protection of the rights of people with disabilities.

${ }^{5}$ Leslie Pickering Francis \& Anita Silvers, Introduction to AMERICANS WITH DISABILITIES: EXPLORING THE IMPLICATIONS OF THE LAW FOR INDIVIDUALS AND INSTITUTIONS xv (Leslie Pickering Francis \& Anita Silvers eds., 2000) [hereinafter AMERICANS WITH DisABILITIES].

642 U.S.C. $\$ \S 12101(b)(2)(1994)$.

7 See 42 U.S.C. $\$ 2000$ e (1964).

${ }^{8}$ Other federal statutes which protect people with disabilities include the Individuals with Disabilities Education Act (IDEA), 20 U.S.C. §§ 1401-1485 (1994 \& Supp. IV 1998) (guaranteeing that each child with disabilities will have "individualized plan" so that he or she can receive "free appropriate education"), the Developmental Disabilities Assistance and Bill of Rights Act of 2000, 42 U.S.C. §§ 15001-15115 (2000) (guaranteeing that individuals with developmental disabilities and their families participate in design of and have access to needed community services, individualized supports and other needs of assistance), the Air Carrier Access Act of 1986, 42 U.S.C. § 41705 (1994) (amended 2000) 
Two distinctive structural features of the ADA stand out in the context of Title I - the definition of "disability" and its role in defining the protected group, and the reasonable accommodation requirement. First, unlike the case for race or sex, protection for people with disabilities raises questions about who should be eligible for protection. Because the ADA grants standing only to individuals who meet the statutory definition of "disabled," it is critical to understand who is covered by that definition. Despite the ADA's apparent attempt at a broad definition of the meaning of "disability," with respect to any individual: 1) physical or mental impairment that substantially limits one or more major life activities; ${ }^{9}$ or 2) a record of such impairment; or 3) being regarded as having such an impairment regardless of whether the individual actually has the impairment, ${ }^{10}$ the definition of disability remains a controversial and hotly litigated issue. ${ }^{11}$ Title I also provides

(prohibits any carrier, including a foreign carrier from discriminating against an otherwise qualified individual with a mental or physical handicap), the Voting Accessibility for the Elderly and Handicapped Act of 1984, 42 U.S.C. §1973ee1-1973ee6 (1984) (improves access for handicapped and elderly individuals to registration facilities and polling places for federal elections), the Rehabilitation Act of 1973, 29 U.S.C. §§ 791-796 (1994 \& Supp III 1997) (creates regulations for employment of disabled individuals under federal government contracts; prohibits any program or activity receiving federal assistance from discriminating against, excluding from participation, or denying benefits to any otherwise qualified individual with disability; orders removal of architectural, transportation, or communication barriers; guarantees that federal employees and members of public who are disabled have same access to and use of information and data as federal employees and members of the public who are not disabled; provides support system in each state to protect legal and human rights of individuals who are otherwise ineligible under 29 U.S.C. $\S 732,42$ U.S.C. $\S 15041$ (2000), 42 U.S.C. § 10801 (1986)), the Fair Housing Act Amendments of 1988 (FHAA), 42 U.S.C. $\S \S 3601-3631$ (1994 \& Supp III 1997) (prohibits discrimination on basis of handicap in sale or rental of housing, in residential real estate related transactions and in provision of brokerage services). For discussion of the history and effectiveness of these statutes, see RUTH COLKER \& BONNIE PODRIAS TUCKER, THE LAW OF DisABILITY DISCRIMINATION (3d ed. 1999).

9 Major life activities include, but are not limited to, caring for one's self, performing manual tasks, walking, seeing, hearing, speaking, breathing, learning and working. 29 C.F.R. § 1630.2(I) (1991). Specific exclusions from the category of major life activities include: temporary physical or mental impairments, current illegal dug use, homosexuality and bisexuality, sexual behavior disorders, predisposition to illness, personality traits, environmental, cultural, or economic disadvantage, advanced age, pregnancy. A major life activity is "substantially limited" within the meaning of the statute if the individual is unable to perform a major life activity that the average person in the general population can perform, or is significantly restricted as to the condition, manner, or duration under which he or she can perform the activity, as compared to the general population. 29 C.F.R.§ $1630.2(\mathrm{~J})$.

1042 U.S.C. $\S 12102(2)(1994)$.

${ }_{11}$ See Paula E. Berg, Ill/Legal: Interrogating the Meaning and Function of the Category of Disability Anti Discrimination Law, 18 YALE L. \& POL'Y REV. 1, 8-23 (1999) (describing historical concepts of disabilities and outlining current case law interpreting disabilities 
that no employer "shall discriminate against a qualified individual with a disability because of the disability of such individual in regard to job application procedures, the hiring, advancement, or discharge of employees, employee compensation, job training, and other terms, conditions, and privileges of employment."12 In addition to those traditional forms of discrimination based on the provisions of Title VII, Title I contains an additional form of discrimination - "not making reasonable accommodations to the known physical or mental limitations of an otherwise qualified individual with a disability who is an applicant or employee, unless [the employer] can demonstrate that the accommodation would impose an undue hardship on the operation of the business." ${ }^{13}$

Despite intense interest in the ADA and its clearly stated goals of providing strong, consistent, and enforceable standards for ending discrimination and fostering economic and social inclusion, there is no consistent understanding of the reasonable accommodation requirement. Indeed, there are at least three distinct distributive outcomes that appear to comport with the requirements of the ADA.

\section{A. Shifting Costs}

Although the ADA is not the first civil rights legislation to use the concept of reasonable accommodation, ${ }^{14}$ it invested reasonable accommodation with significant and far-reaching meaning. For that reason, the ADA is thought to go farther than traditional civil rights laws because it requires employers to do more than simply treat individuals with disabilities the same way as other similarly qualified applicants or workers. Indeed, the ADA imposes on employers an obligation to

${ }_{14}$ Prior to the ADA, "reasonable accommodation" had been used in two, very different contexts. Reasonable accommodation is used in $\S 504$ of the Rehabilitation Act of 1973, which applies to schools and housing providers receiving federal assistance. 29 U.S.C. \& 794 (1994). Reasonable accommodation is also used in the context of Title VII's prohibition on discrimination on the basis of religion. See 42 U.S.C. 2000e(j) (1988). In TWA $v$. Hardison, 432 U.S. 63 (1977), the court interpreted 2000e(j) as no more than de minimis cost to employer and severely restricted the application of the law to avoid conflict with the First Amendment prohibition against establishing religion. See also Robert L. Burgdorf, Jr., The Americans with Disabilities Act: Analysis and Implications of a Second Generation Civil Rights Statute, 26 HARV. C.R. - C.L. L. REV. 413, 511-14 (1991) (discussing different interpretations of "reasonable accommodations" for religion and disability). The legislature, in the context of the ADA, specifically rejected the latter interpretation. H.R. REP. NO. 101-485(II), at 68 (1990), reprinted in 1990 U.S.C.C.A.N. 303, 350.
} 
provide reasonable accommodation to make it possible for people with disabilities to perform essential job functions and to secure equal enjoyment of all terms and conditions of employment. This obligation applies whether or not there is a finding of prior wrongful conduct. In that sense, the reasonable accommodation requirement shifts the costs of accommodation from the employee to the employer. ${ }^{15}$

As defined by the ADA, reasonable accommodation is a flexible, interactive, and personalized process. Reasonable accommodation may include "making existing facilities used by employees readily accessible to and usable by individuals with disabilities; and job restructuring, parttime, or modified work schedules, reassignment to a vacant position, acquisition or modification of equipment or devices, appropriate adjustment or modifications of examination, training materials or policies, the provision of qualified readers or interpreters, and other similar accommodations for individuals with disabilities." ${ }^{16}$ Indeed, there have been significant court decisions ruling that reasonable accommodation includes such changes as specialized testing, training or other work procedures, ${ }^{17}$ provision of specialized equipment or other

15 This process might more accurately be called re-shifting, as costs first were shifted from individuals with disabilities to the federal government through various entitlement programs, and then shifted to employers through operation of the ADA. An estimated $\$ 200$ billion dollars a year in government expenditures support people with disabilities. See Sen. Tom Harkin, The Americans with Disabilities Act: Four Years Later - Commentary on Blanck, 79 IOWA L. REV. 935, 937 (1994) (quoting former President Bush's observation that it costs American people nearly $\$ 200$ billion annually to support people with disabilities).

1642 U.S.C. $\S 12111(9)(1994)$

17 See, e.g., Vollmert v. Wisconsin Dept. of Transp., 197 F.3d 293, 302 (7th Cir. 1999) (finding that under ADA, employer did not reasonably accommodate learning disabilities that interfered with employee's ability to master new computer system when it provided her with training on new system, where employer was aware of her disabilities, was made specifically aware of need for specialized training by physician's letter, and yet refused to provide training sufficiently designed to address her disability, and refused her request for tutor trained in learning disabilities after she indicated that tutor likely was available free of charge through government agency); Meisser v. Hove, 872 F. Supp. 507, 509 (N.D. Ill. 1994) (ordering employer to provide the deaf plaintiff with, among other things, speech therapy, further job opportunities which would enhance his skills to compete meaningfully for future positions, and to provide professional evaluations of his speech); Arneson v. Sullivan, 946 F.2d 90 (8th Cir. 1991) (ordering employer to reinstate employee to his position of claims representative and to provide him with computer training on new computer system); American Fed'n of Gov't Employees, Local 51 v. Baker, 677 F. Supp. 636 (N.D. Cal. 1987) (ordering employer, United States Mint, to provide accommodation, including specialized training, job restructuring, reassignment, and special equipment, as well as individualized accommodations including training which reflected slower paced presentation of instructions, modeling, verbal and/or physical prompts, and repetition, as well as assisting devices such as gloves, rubber tips, magnifying glasses, and equipment to make lifting and carrying easier); Stutts v. Freeman, 694 F.2d 666, 669 (11th Cir. 1983) 
physical modifications of the workplace, ${ }^{18}$ and job restructuring. ${ }^{19}$ The employer may choose the type of accommodation, with no obligation to make the most efficacious or best accommodation possible or every accommodation required, as long as the accommodation made enables

(holding that when employer utilizes test to determine applicant's eligibility for position, handicapped applicant must be accommodated by use of test that accurately reflects handicapped applicant's abilities). But see Mitchell v. Washingtonville Cent. Sch. Dist., 190 F.3d 1, 9 (2d Cir. 1999) (school district not required under ADA to retrain and assign disabled head custodian to entirely different position, such as courier or bus dispatcher, which positions were not available at relevant time); Needle v. Alling \& Cory, Inc., 88 F. Supp. 2d 100 (W.D.N.Y. 2000) (finding employer has no obligation to retrain disabled employee for position for which he is not qualified).

${ }_{18}$ See e.g., Davis v. Lockheed Martin Operations Support, Inc., 84 F. Supp. 2d (D. Md. 2000) (finding reasonable under ADA former employer's six-week schedule, by which former employee with disabling entrapment of certain nerves, which caused her pain in groin and upper thigh, would gradually increase her hours back to 40-hour week, and employer's installation of ergonomic chair, adjustable workstations, elevated computer table, and cot); Vande Zande v. Wisconsin Dep't of Admin., 851 F. Supp. 353 (W.D. Wis. 1994), aff'd 44 F.3d 538 (7th Cir. 1994) (finding that employer had adequately accommodated plaintiff by making several modifications to a kitchenette when constructing new facilities for plaintiff's department); Fink v. New York City Dep't of Pers., 53 F.3d 565 (2d Cir. 1995) (finding that employer sufficiently accommodated visually impaired candidates for promotion by providing them with tape recording of examination, tape recorder, reader-assistant to help with operation of recorder and to read questions and answers, private room, and double time afforded to other candidates); Davis v. York Int'l, Inc., 1993 WL 524761, *8 (D. Md.) (finding as reasonable accommodation employer's providing computer equipment at employee's home in order to allow her to complete her work, because her Multiple Sclerosis caused her to become increasingly distracted when in office environment).

19 See, e.g., Santiago v. Executive Airlines, 41 F. Supp. 2d 129, 136-37 (D.P.R. 1999) (finding that airline's reassignment of employee with ear condition from flight attendant to ramp escort position, rather than granting employee's request to fly only in pressurized aircraft, was a reasonable accommodation under ADA); Karsbusicky v. City of Park Ridge, 950 F. Supp. 878, 884-85 (N.D. Ill. 1997) (finding reassignment of police officer with congenital total hearing loss in left ear to a community service officer position to be reasonable accommodation); Hennenfent v. Mid Dakota Clinic, 164 F.3d 419, 422 (8th Cir. 1998) (finding clinic extended reasonable accommodation within meaning of ADA to physician for leg amputation resulting from diabetes, where it provided him with reduced work schedules, extended leaves of absence, and backup physicians to assist him with his on-call duties); Schwertfager v. City of Boyton Beach, 42 F. Supp. 2d 1347, 1364-65 (S.D. Fla. 1999) (finding city provided employee who had breast cancer and reconstructive surgery ample accommodations to achieve qualifications required to perform essential functions of her position, and thus, employee did not establish prima facie case under ADA; employee was provided assistance and training, and was paid her full salary for extended period of time after her surgery, and even after she was reassigned to position of less responsibility, she retained her title and salary, though her job functions were greatly reduced); $c f$. Norville v. State Island University Hosp., 196 F.3d 89 (2d Cir. 1999) (reassignment does not constitute reasonable accommodation under the ADA where a position comparable to the employee's former placement is available, for which the employee is qualified, but the employee instead is assigned to a position that would involve a significant diminution in salary, benefits, seniority and other advantages that she possessed in her former job). 
the employee to perform the essential job functions and provides the employee with employment benefits equivalent to those of other employees. $^{20}$

The apparent breadth of the ADA's reasonable accommodation standard is bounded by the undue hardship defense. "Undue hardship" is defined broadly as an action requiring significant difficulty or expense when considered in light of such factors as the nature and cost of the accommodation needed, the overall financial resources of the facility involved or of the employer, the type of operation or operations of the employer, $^{21}$ and potential disruption to other workers and the production process. ${ }^{22}$

Prior to its passage in 1990, the ADA was "greeted with enthusiasm by people with disabilities who expected it to produce a noticeable expansion of employment opportunities, and with enormous concern by employers who fear that its requirement to accommodate workers' disabilities will dramatically increase costs directly or via litigation." ${ }^{23}$ Despite the promise of the ADA, this has not proven to be true. Although there have been significant court decisions ruling that reasonable accommodation includes such changes as specialized testing, training or other work procedures, provision of specialized equipment or other physical modifications of the workplace, and job restructuring, available data indicates that people with disabilities are failing to achieve a noticeable expansion of employment opportunities. Although there is no way of discerning the number or frequency of individual acts of discrimination against people with disabilities, post-ADA research has "consistently demonstrated that people with disabilities have lower average wages and employment rates than individuals without disabilities." ${ }^{\prime 2}$

The concern that the reasonable accommodation requirement would dramatically increase costs of employing people with disabilities also appears largely unfounded. Although the size of the financial burden on employers as a result of the reasonable accommodation requirement is not clear, a review of the available data suggests that the majority of

See 29 C.F.R. app. $\S 1630.9$ (1995).

2142 U.S.C. $\S 12111(10)(1994)$.

22 See 29 C.F.R. $\S 1630.2(\mathrm{p})(2)(\mathrm{v})$ (1993).

${ }^{23}$ Nancy R. Mudrick, Employment Discrimination Laws of Disability: Utilization and Outcome, 549 ANNALS AM. ACAD. POL. \& SOC. SCI. 53, 54 (1997).

${ }_{24}$ Marjorie Baldwin, Can the ADA Achieve its Employment Goals?, 549 ANNALS AM. POL. \& SOC. SCI. 41-42 (1997). 
accommodations cost less than $\$ 100$ per employee. ${ }^{25}$ In fact, the direct costs of accommodation of workers with disabilities may be even lower, as many companies regularly make informal accommodations that require minor and cost-free workplace adjustments and that may enable employees with and without disabilities to perform jobs productively, cost-effectively, and safely. ${ }^{26}$

\section{B. Sharing Costs}

One important substantive goal of the ADA is to encourage parties to share information held by the person with a disability, such as his or her specific limitations and abilities, and the information held by the employer, such as the essential functions of the job and the feasibility of various reasonable accommodations, in negotiations over possible accommodations. ${ }^{27}$ Indeed, several courts have held that employees must inform their employer of their disability in order to trigger the duty to accommodate and reveal medical information necessary for devising an accommodation, ${ }^{28}$ and that the employer has a duty to confer with

25 A 1994 report from the President's Committee on Employment of People with Disabilities found that since October 1992, 68\% of the accommodations made for workers with disabilities cost $\$ 500$ or less. See Steven B. Epstein, In Search of a Bright Line: Determining When an Employer's Financial Hardship Becomes "Undue" Under the Americans with Disabilities Act, 48 VAND. L. REV. 391, 394 n.11 (1995). Materials in the ADA's legislative history indicate costs to businesses for reasonable accommodations are expected to be less than $\$ 100$ per worker for $30 \%$ of workers needing an accommodation, with $50 \%$ of those needing an accommodation requiring no expense at all. S. REP. NO. 116 (1989). A study commissioned by Sears, Roebuck, and Co. indicated that $69 \%$ of the reasonable accommodations provided by the company cost nothing, $28 \%$ cost less than $\$ 1,000$, and only $3 \%$ cost more than $\$ 1,000$. Moreover, the average cost to Sears of providing workplace accommodations to employees with disabilities was less than $\$ 50$, compared with an average cost of $\$ 1,800$ and $\$ 2,400$ for terminating and replacing an employee, respectively. See Peter David Blanck, Transcending Title I of the Americans with Disabilities Act: A Report on Sears, Roebuck and Co., 20 MENTAL \& PHYSICAL DisABILITY L. REP. 278, 279 (1996). A 1982 Department of Labor study finding only $22 \%$ of individuals with disabilities received any form of accommodation under the Rehabilitation Act, and of that group $51 \%$ of the accommodations imposed no costs and 30\% imposed a cost of less than $\$ 500$ per worker. See Bonnie P. Tucker, The Americans with Disabilities Act: An Overview, 1989 U. ILL. L. Rev. 923, 930 (1989).

26 Blanck, supra note 25, at 379-80.

${ }_{27}$ Pamela S. Karlan \& George Rutherglen, Disabilities, Discrimination, and Reasonable Accommodation, 46 DUKE L. J. 1 (1996).

${ }_{28}$ See, e.g. Barnett v. U.S. Air, 228 F.3d 1105, 1112 (9th Cir. 2000); Taylor v. Phoenixville School Dist., 184 F.3d 296, 313 (3d Cir. 1999); Fjellestad v. Pizza Hut, 188 F.3d 944, 951 (8th Cir. 1999); Grenier v. Cyanamid Plastics, 70 F.3d 667, 677 (1st Cir. 1995); Smith v. Midland Brake, 180 F.3d 1154, 1171-72 (10th Cir. 1999); 125 F.3d 1432, 1434-36 (11th Cir. 1997); Taylor v. Principal Fin. Group, 93 F.3d 155, 163-65 (5th Cir. 1996). 
individuals with disabilities over requested accommodations. ${ }^{29}$

Pamela S. Karlan and George Rutherglen assert that the structure of the reasonable accommodation and undue hardship doctrines operates to create a zone of bargaining. ${ }^{30}$ Because compensatory and punitive damages are available to the individual with a disability only upon proof of lack of good faith effort to accommodate on the part of the employer, ${ }^{31}$ it is likely that employers will offer some accommodation. The potential plaintiff also faces a substantial risk in the courts. Thus the potential litigant must carefully weigh the potential return from litigation against the value of the job with the presumably lesser level of accommodation offered.

The result is a bargaining range, where the minimum the individual with a disability is willing to accept is less than the maximum the employer is willing to offer. Karlan and Rutherglen conclude:

The relatively low cost of many modifications, the safe harbor against damages provided to employers who negotiated in good faith and the risks attendant on litigation all make it likely that employers will offer accommodations. At the same time, the relatively high search costs and dislocation expenses faced by many disabled individuals make it likely that they will accept the employer's proffered accommodation, even if it is far from perfect. In these cases, employer and employee essentially share the costs of

29 See, e.g. Jackan v. New York State Dept. of Labor, 205 F.3d 562, 566 (2d Cir. 2000); Rehling v. City of Chicago, 207 F.3d 1009, 1015 (7th Cir. 2000); Fjellestad, 188 F.3d at 951; Barnett, 228 F.3d at 1112; Phoenixville School Dist., 184 F.3d at 311; Midland Brake, 180 F.3d at 1171-72; EEOC v. Prevo's Family Market, 135 F.3d 1089, 1095 (6th Cir. 1998); 125 F.3d at 1134; Principal Fin. Group, 93 F.3d at 165; Beck v. Univ. Wis. Bd. of Regents, 75 F.3d 1130, 1135 (7th Cir. 1996); Cyanamid Plastics, 70 F.3d at 677.

${ }_{30}$ Karlan \& Rutherglen, supra note 27, at 30; see also Richard V. Burkhauser, The American With Disabilities Act: Social Contract or Special Privilege; Post-ADA; Are People With Disabilities Expected to Work?, 549 ANNALS 71, 79 (1997) ("When a pathology begins to affect the ability to work, important job related decisions must be made by both worker and employee. These decisions may also be influenced by government policies. The worker will consider the relative rewards of continued work versus applying for transfer benefits. In like manner, the social institutions and legal mandates within which the firm must operate will influence an employer's willingness to accommodate the work.").

${ }_{31}$ The remedies available under the ADA are the same as those available under Title VII. Before an individual can file a lawsuit, he or she must file a charge with the EEOC and/or the relevant state agency and receive a right-to-sue letter. The remedies for violation of Title I include injunctive relief, back pay, job reinstatement, attorney's fees, and compensatory and punitive damages in the case of intentional discrimination. Under the Civil Rights Act of 1991, compensatory and punitive damages are based on the size of the employer, and the maximum amounts range from $\$ 50,000$ to $\$ 300,000$. See 42 U.S.C. $\S$ 1981a(b)(3) (1994). 
the disability. ${ }^{32}$

\section{Avoiding Costs}

In the employment context, the ADA prohibits an employer from discriminating on the basis of disability against a qualified individual with a disability in regard to, among other things, fringe benefits including employer-sponsored pension and welfare benefits. ${ }^{33}$ One such benefit is employee participation in an employer-sponsored disability benefits plan.

Disability benefit plans provide income-replacement benefits to employees who are unable to work because of illness or accident. The purpose of such an insurance plan, which may be either employersponsored or privately purchased, is to replace some or all of the income lost when an employee is suffering from a disability, as defined by the policy at issue. There are two general types of definitions of disability in ERISA-regulated plans. The first defines disability as the employee's inability to perform the material duties of her own occupation. ${ }^{35}$ The second type defines disability as the employee's inability to perform any occupation or, more narrowly, any occupation for which she is suited by education, training, or experience. ${ }^{36}$ Frequently, plans incorporate both

32 Karlan \& Rutherglen, supra note 27, at 30.

33 See 29 C.F.R § 1630.4(f) (1993).

${ }_{34}$ Employer-sponsored disability insurance plans may be either short-term or longterm in nature. Under a short-term plan an employee receives a portion of her regular wages for a specified period of disability generally not to exceed 26 weeks. Long-term benefit coverage usually starts after short-term disability income benefits cease. Long-term benefit coverage provides a partial income replacement benefit to employees who are not likely to return to work because of the total and/or permanent nature of their disabilities.

${ }_{35}$ See, e.g., Lown v. Continental Cas. Co., 238 F.3d 543, 549 (4th Cir. 2001) ("continuously unable to perform the substantial and material duties of his regular occupation . . . and under the regular care of a licensed physician other than himself"); Glover v. Smith Central Bell Tel. Co., 644 F.2d 1155, 1158 (5th Cir. 1980) ("unable to substantially perform all of the material acts of his particular job in the usual and contemporary way"); Mizzell v. Paul Revere Life Ins. Co., 118 F. Supp. 2d 1016,1020 (C.D. Cal. 2000) ("unable to perform the important duties of his own occupation on a full-time or part-time basis because of an injury or sickness that started while insured under [the] policy"); Hughes v. Life Ins. Co. of North America, 112 F. Supp. 2d 780, 782-783 (S.D. Ind. 2000) ("unable to perform all the material duties of his regular occupation"); Gonyea v. John Hancock Mutual Life Ins. Co., 812 F. Supp. 445, 446 n.1 (D. Vt. 1993) ("able to perform none of the usual and customary duties of your occupation"); Brassord v. Continental Cas. Co., 630 F. Supp. 951, 955 (D. Conn. 1986) ("completely unable to perform each and every duty of your occupation because of accidental bodily injury or disease").

36 See, e.g., Myers v. Hercules, 253 F.3d 761, 766 (4th Cir. 2001) ("not able to engage in any employment for wage or profit for which [she is] reasonably qualified by training, 
definitions in a two-phase structure, with an initial "own occupation" stage of between one and two years, and a continuing "any occupation" phase lasting until normal retirement age. ${ }^{37}$ Typically, employees

education, or experience"); Herzberger v. Standard Ins. Co., 205 F.3d 327, 333 (7th Cir. 2000) ("whether the applicant is unable to perform the duties of the job for which he is reasonably fitted by his training or experience"); Hammond v. Fidelity and Guard. Life Ins. Co., 965 F.2d 428,431 (7th Cir. 1992) ("unable to perform all of the substantial and material acts necessary to the prosecution of some gainful business or occupation"); Rendulic v. Kaiser Aluminum \& Chemical Corp., 166 F. Supp. 2d 326, 329 (W.D. Pa. 2001) ("unable to do any work for pay or profit for which [he or she] is or could become reasonably qualified by education, training, or experience"); Andrews v. Standard Ins. Co., 2000 WL 549466, at *2 (N.D. Ill. 2000) ("is unable to perform with reasonable continuity the material duties of any gainful occupation for which [he is] reasonably fitted by education, training or experience"); Eriksen v. Metropolitan Life Ins. Co., 39 F. Supp. 2d 864, 867 (E.D. Mich. 1999) ("not be able to engage in any type of work"); Torimino v. United Food and Commercial Workers Intern. Union Industry Pension Fund, 548 F. Supp. 1012, 1014 (E.D. Mo. 1982) ("[the employee] has been totally disabled by bodily injury or disease so as to be prevented from engaging in any further employment except for such employment or gainful pursuit at which he is unable to earn more than $\$ 100$ per month ... [s] uch disability will be permanent and will continue during the remainder of his life").

37 See, e.g., Aboul-Fetouh v. Employee Benefits Committee, 245 F.3d 465, 468 (5th Cir. 2001) ("during the Elimination Period and for the next twenty-four (24) months, the Member is prevented by Disability from doing all the material and substantial duties of his own occupation. After that, "Totally Disabled" means that the Member is prevented by such Disability from doing any occupation or work for which he is or could become qualified by training, education, or experience"); Schindler v. Metropolitan Life Ins. Co., 141 F. Supp. 2d 1073, 1075 n.2 (M.D. Fla. 2001) ("unable to perform the material duties of your regular occupation ... during the next 12 consecutive months, whether or not the monthly benefits are paid for each of these months. Thereafter, you must be totally incapable due to illness or injury from performing the material duties of any gainful occupation for which you are reasonably fit in training, education or experience."); Demyan v. Sun Life Assurance Co. of Canada, 148 F. Supp. 2d 1316, 1319 (S.D. Fla. 2001) ("in a continuous state of incapacity due to illness which 1. while it continues through the Elimination Period and during the following 36 months of incapacity, prevents him from performing the material and substantial duties of his regular occupation, and 2. while it continues thereafter, prevents him from performing the material and substantial duties of any occupation for which he is or becomes qualified by education, training or experience"); Archible v. Metropolitan Life Ins. Co., 85 F. Supp. 2d 1203, 1205 (S.D. Ala. S. Div. 2000) ("During the first 24 months of your disability, in addition to your Qualifying Period, you must be unable to perform the normal duties of your regular occupation for any employer and you must at no time engage in any occupation or employment for pay or profit. This must be due to your disability. . . After the first 24 months of your disability, in addition to your Qualifying Disability Period, you must be completely unable to engage in any occupation or employment for which you are or become qualified. You could be qualified because of your education, training or experience."); Hotaling v. Teachers Ins. and Annuity Ass'n of America, 62 F. Supp. 2d 731,739 (N.D.N.Y. 1999) (“(a) For the first thirty months of Disability, being completely unable due to sickness, bodily injury, or pregnancy to perform your normal occupation and not performing any other occupation; and (b) after the first thirty months, being unable due to sickness, bodily injury, or pregnancy to perform any occupation for which you are reasonably suited by education, training, or experience"); Sova v. Wheaton Franciscan Services, Inc. Health and Welfare Ben. Trust, 40 F. Supp. 2d 
applying for disability benefits are required by the terms of the plan to submit sufficient objective medical evidence of their disabilities. ${ }^{38}$

Most employee-sponsored welfare plans, including disability benefits plans, are governed by ERISA. ERISA was enacted to encourage employer formation of and to protect employees' rights to pension plans and welfare benefits plans by requiring uniformity in the administration of benefits plans. It contains a broad preemption clause, that preempts state law insofar as it "relates to" employee benefit plans, ${ }^{39}$ and provides the exclusive remedial scheme for claims relating to employee benefits plans. $^{40}$

Unfortunately, ERISA-regulated disability benefits and the structure of ERISA's remedial scheme can be used by employers to avoid the duty of reasonable accommodation of employees with disabilities. Consider an employee who experiences a disability but remains willing and able to work with some accommodation. ${ }^{41}$ She notifies her employer of the disability. Depending on her familiarity with the ADA and/or the

1031, 1033 (E.D. Wis. 1999) (“the complete inability of the participant, due to injury and/or illness, to perform all the important daily duties of his regular occupation for a twenty-four (24) month period beginning from the date of the disablement. For any period extending beyond an initial twenty-four (24) month period, total disability means the complete inability of the participant to perform the important daily duties of any occupation for which the participant may be or may become qualified for by any reason of education and/or training and/or experience"); Peterson v. Continental Cas. Co., 116 F. Supp. 2d 532, 535 (S.D.N.Y. 2000) ("during [the first 24 months] . . continuously unable to perform the substantial and material duties of Your regular occupation... [after 24 months] continuously unable to engage in any occupation for which You are or become qualified by education, training or experience").

${ }_{38}$ See Wojciechowski v. Metropolitan Life Ins. Co., 2001 WL 38264, at *2 (2d Cir. Jan. 12, 2001); Skretvedt v. E.I. DuPont de Mours and Co., 268 F.3d 167, 171-72 (3d Cir. 2001); Myers, 253 F.3d at 763; Gooden v. Provident Life and Acc. Ins. Co., 250 F.3d 329, 331 (5th Cir. 2001); Delta Family Care Disability and Survivorship Plan v. Marshall, 258 F.3d 834, 837-38 (8th Cir. 2001); Walke v. Group Long Term Disability Ins., 256 F.3d 835, 838 (8th Cir. 2001); Regula v. Delta Family Care Disability and Survivorship Plan, 266 F.3d 1130, 1133 (9th Cir. 2001); Levinson v. Reliance Standard Life Ins. Co., 245 F.3d 1321, 1324 (11th Cir. 2001); Pari-Fasano v. ITT Hartford Life and Acc. Ins., 230 F.3d 415, 417-18 (1st Cir. 2000); Postma v. Paul Revere Life Ins. Co., 223 F.3d 533 (7th Cir. 2000); Cochran v. Trans-General Life Ins. Co., 60 F. Supp. 2d 693, 695 (E.D. Mich. 1999).

39 The "Preemption Clause" provides, "[e]xcept as provided in [the Savings Clause]...[ERISA shall] supercede any and all state laws insofar as they may not or hereafter relate to any employee benefit plan. 29 U.S.C. § 1144(a) (1994). The "Savings Clause" exempts state insurance, banking and securities law from preemption. 29 U.S.C. § 1144(b)(2)(A). However, self-funded employee welfare plans cannot be deemed insurance plans under the "Deemer Clause". 29 U.S.C. $\$ 1132$ (1994).

4029 U.S.C. $\S 1132$.

${ }^{41}$ This discussion does not address workers who claim they have a record of a substantially limiting impairment, or are regarded has having such impairment. 
feasibility of various potential accommodations, she may or may not request accommodation of her disability from her employer. Imagine that the employer is either unaware of the necessity for, or is unwilling or unable to provide, accommodation for the employee, and instead suggests, encourages, or forces our employee to leave the workplace on temporary or permanent disability leave. Because employer-sponsored disability plans rarely define disability with reference to reasonable accommodation, ${ }^{42}$ it is entirely possible that the employee may receive disability benefits even though she is able to perform her job with reasonable accommodation. As a result, our employee falls into a gap between the definition of disability contained in her employer's disability leave policy and the definition of disability contained in the ADA.

Although a plaintiff seeking or receiving disability benefits under an employee disability benefits plan, based on proof that the plaintiff is unable to work, is not necessarily barred from simultaneously contending that her employer discriminated against her under the $\mathrm{ADA}^{43}$ once our employee is placed on disability her standing to assert the rights created by the ADA is jeopardized. In order to have standing to challenge an employer-provided disability insurance policy as discriminatory under the ADA, a plaintiff must be a "qualified individual with a disability," defined as "an individual with a disability who, with or without reasonable accommodation, can perform the essential functions of the employment position that such individual holds or desires." ${ }^{\prime 4}$ At least four Circuits have found that a disabled former employee is not a qualified individual with a disability as defined by the ADA and therefore does not have standing to sue her exemployer under Title I. ${ }^{45}$ In the alternative, if the disabled former

${ }_{42}$ See Cleveland v. Policy Management Systems Corp, 526 U.S. 795, 803 (1999) (the definition of "individual with a disability" for purposes of Social Security Disability Insurance (SSDI) benefits does not take the possibility of reasonable accommodation into account).

${ }^{43}$ See Policy Management Systems Corp., 526 U.S. at 802-03 (holding that claims for SSDI benefits and for ADA damages do not inherently conflict). For a discussion of this issue, see generally Maureen C. Weston, The Road Best Traveled: Removing Judicial Roadblocks that Prevent Workers from Obtaining Both Disability Benefits and ADA Civil Rights Protection, 26 HOFSTRA L. REV. 377 (1997).

4442 U.S.C. § 12111 (1994) ("For the purposes of this sub-chapter, consideration shall be given to the employer's judgment as to what functions of a job are essential, and if an employer has prepared a written job description before advertising or interviewing applicants for the job, this description shall be considered evidence of the essential functions of the job.").

${ }^{45}$ The Sixth, Seventh, Ninth and Eleventh Circuits have found that a disabled former 
employee is able to get her case into court as a claim under ERISA, she will most likely face a bench trial ${ }^{46}$ governed by an arbitrary and capricious standard of review ${ }^{47}$ and limited to the evidence in the

employee is not a "qualified individual with a disability," and therefore lacks standing to sue his or her former employer under the ADA. See Morgan v. Joint Admin. Bd., Ret. Plan of the Pillsbury Co., 268 F.3d 456, 457-99 (7th Cir. 2001); EEOC v. CNA Ins. Co., 96 F.3d 1039, 1044-45 (7th Cir. 1996); Weyer v. Twentieth Century Fox Film Corp., 198 F.3d 1104, 1109 (9th Cir. 2000); Parker v. Metropolitan Life Ins. Co., 99 F.3d 181, 186-87 (6th Cir. 1996) rev'd on other grounds, 121 F.3d 1006, 1008-09 (6th Cir. 1997); Gonzales v. Garner Food Services, Inc., 89 F.3d 1523, 1526 (11th Cir. 1996); see also Bass v. City of Orlando, 57 F. Supp. 2d 1318, 1323 (M.D. Fla. 1999); Fitts v. Federal Nat. Mortg. Ass'n, 44 F. Supp. 2d 317, 321 (D.D.C. 1999); Fennell v. Aetna Life Ins. Co., 37 F. Supp. 2d 40, 43 (D.D.C. 1999); Beatty v. City of Wheaton, 1999 WL 91909, at *2 (N.D. Ill. Feb. 11, 1999); Erwin v. Northwestern Mut. Life Ins. Co., 999 F. Supp. 1227, 1230 (S.D. Ind. 1998), Fobar v. City of Dearborn Heights, 994 F. Supp. 878, 882 (E.D. Mich. 1998); Bril v. Dean Witter, Discover \& Co., 986 F. Supp 171, 176 (S.D.N.Y. 1997). Neither the EEOC regulation nor the interpretive guidance address the standing issue. The EEOC has taken the position in litigation that a former employee has standing to sue under the ADA so long as he or she is qualified to receive benefits. See Stephen F. Befort, Mental Illness and Long-Term Disability Plans Under the Americans with Disabilities Act, 2 U. PA. J. LAB. \& EMP. L. 287, 293 (1999) (citing Leonard F. v. Israel Discount Bank of New York, No. 95 Civ. 6964, 1996 WL 634860, at *3 (S.D.N.Y. Sept. 24, 1996)).

Nor may the employee bring suit against the insurance provider of a long-term disability benefit policy as a "public accommodation" under Title III of the ADA. See Weyer, 198 F.3d 1104, 1115 (9th Cir. 2000); Ford v. Schering-Plough Corp., 145 F.3d 601, 612 (3rd Cir. 1998); Parker v. Metropolitan Life Ins. Co, 121 F.3d 1006, 1011 (6th Cir. 1997). But see Conners v. Maine Medical Center, 46 F. Supp. 2d 34, (D. Me. 1999).

46 The majority of the Circuits have held that there is no statutory right to a jury trial in an action for benefits under ERISA 29 U.S.C. § 1132(e) (1994). See Katsaros v. Cody, 744 F.2d 270 (2d Cir. 1984); Cox v. Keystone Carbon Co., 894 F.2d 647 (3d Cir. 1990); Berry v. Ciba-Geigy Corp., 761 F.2d 1003 (4th Cir. 1985); Calamia v. Spivey, 632 F.2d 1235 (5th Cir. 1980); Bair v. General Motors Corp., 895 F.2d 1094 (6th Cir. 1990); Wardle v. Central States, Southeast and Southwest Areas Pension Fund, 627 F.2d 820 (7th Cir. 1980); Smith v. City of Des Moines Iowa, 99 F.3d 1466 (8th Cir. 1996), Nevill v. Shell Oil Co., 835 F.2d 209 (9th Cir. 1987); Zimmerman v. Sloss Equipment, Inc., 72 F.3d 822 (10th Cir. 1996); Broaddus v. Florida Power Corp., 145 F.3d 1283 (11th Cir. 1998).

47 In 1989, the Supreme Court held that the standard for review of an ERISA-regulated benefits decision is determined by the terms of the plan - the standard is de novo, unless the benefits plan gives the administrator or fiduciary discretionary authority to determine eligibility for benefits or to construe the terms of the plan in which case the standard of review is abuse of discretion. Firestone v. Bruch, 489 U.S. 101 (1989). Although the plan must properly designate a delegate of the fiduciary's discretionary authority, see Rodriquez-Abreu v. Chase Manhattan Bank, N.A., 986 F.2d 580, 584 (1st Cir. 1993), no "magic words" are required to confer discretion. See DeNobel v. Vitro Corp., 885 F.2d 1180, 1187 (4th Cir. 1989). Courts appear to require language which specifically states "discretion to determine questions regarding benefits eligibility." Jordan v. Ret. Comm. of Rensselaer Polytechnic Inst., 46 F.3d 1264 (2d Cir. 1995); Mitchell v. Eastman Kodak Co., 113 F.3d 433 (3d Cir. 1997); Haley v. Paul Revere Life Ins. Co., 77 F.3d 84, 88-89 (4th Cir. 1996); Patterson v. Hughes Aircraft Co., 11 F.3d 948 (9th Cir. 1993). There is an exception for situations where the decisionmaker is operating under a conflict of interest. Firestone, 489 U.S. at 115 . What is required to demonstrate a conflict of interest as well as the effect of 
administrative record. ${ }^{48}$

\section{Defining Disability: An Alternative Medical Model}

One reason for the inconsistent outcomes identified above is the failure to develop a coherent and consistent theory of disability. Indeed, "[o]ne of the most contentious aspects of disability law, research, and policy involves the definition of disability." ${ }^{\prime 49}$ In many respects, the courts have treated the ADA as a straightforward extension of traditional civil rights protections to people with disabilities. However, theoretical treatment of the ADA is less common than that afforded other civil rights statutes, and disability remains undertheorized — "[c]ompared with the enormous volume of literature about race and gender, little attention has been paid to the theoretical understanding of disability. ${ }^{\prime 50}$ Moreover, although the ADA is modeled on Title VII, authors have correctly noted that the indiscriminate reliance on Title VII as a precedent directs attention away from the distinctiveness of the ADA and the important task of developing a theory of disability and disability-based discrimination. ${ }^{52}$

a conflict of interest remain the subject of litigation. See What Standard of Review Applies When the Decision Maker Has a Conflict of Interest (Part I), ERISA LITIGATION ALERT, Mar. 2000, at 11; Alan P. Woodruff, What Standard of Review Applies When the Decision Maker Has a Conflict of Interest (Part II), ERISA LITIGATION ALERT, Apr. 2000, at 1.

${ }_{48}$ In a case governed by the arbitrary and capricious standard of review, the circuit courts are uniform in holding that a court is allowed to consider only the evidence presented to the decisionmaker at the time of the decision. See generally Bernstein v. Capitalcare, Inc., 70 F.3d 783 (4th Cir. 1995); Donato v. MetLife, 19 F. 3d 375 (7th Cir 1994); Southern Farm Bureau Life Ins. Co. v. Moore, 993 F.2d 98 (5th Cir. 1993); Miller v. MetLife, 925 F.2d 979 (6th Cir. 1991); Oldenberger v. Central States, Southeast and Southwest Areas Teamsters Pension Fund, 934 F.2d 171 (8th Cir. 1991); Winters v. Costco Wholesale Corp., 49 F.3d 550 (9th Cir. 1995); Sandoval v. Aetna Life and Cas. Ins. Co., 967 F.2d 377 (10th Cir. 1992); Jett v. Blue Cross \& Blue Shield of Alabama, Inc., 890 F.2d 1137 (11th Cir. 1990).

${ }_{49}$ Peter David Blanck \& Mollie Weighner Marti, Attitudes, Behavior and the Employment Provisions of the Americans with Disabilities Act, 42 VILL. L. REV. 345, 352 (1997).

${ }^{50}$ Francis \& Silvers, supra note 5, at xxiv.

51 See H.R. REP. NO. 101-485, pt. III, at 26, reprinted in U.S.C.C.A.N. 445, 449 (1990).

${ }_{52}$ See, e.g., S. Elizabeth Wilborn Malloy, Something Borrowed, Something Blue: Why Disability Law Claims Are Different, 33 CONN. L. ReV. 603 (2001); Steven L. Wilborn, A Nested Model of Discrimination, www.legalessays.com (1999); see also Stephen Befort \& Holly Lindquist Thomas, The ADA in Turmoil: Judicial Dissonance, the Supreme Court's Response and, the Future of Disability Discrimination Law, 78 OR. L. REV. 27, 68 (1999); Bonnie P. Tucker, The ADA's Revolving Door: Inherent Flaws in the Civil Rights Paradigm, 62 OHIO ST. L.J. 335 (2001) [hereinafter Tucker, Revolving Door]. 


\section{A. The Traditional Medical Model of Disability}

\section{The History: A Progression of Models of Disability}

More than a decade ago, political scientist Richard Scotch identified a series of theoretical paradigms to explain how disability has been conceptualized historically in Western society: the moral model, the medical model, the economic model, the social model, and the civil rights model. ${ }^{53}$

The earliest model, the moral model, interprets disability as a reflection of sinfulness and inner spiritual inferiority. ${ }^{54}$ Although vestiges of the moral model remain in modern disability policy, ${ }^{55}$ for more than one hundred years, "disability has been defined in predominantly medical terms as a chronic functional incapacity whose consequence was functional limitations assumed to result from physical or mental impairment." ${ }^{\prime 56}$ The defining characteristic of the medical model is the view that disability is an individual, personal trait of the person in whom it inheres. ${ }^{57}$ The disabled individual is viewed as innately biologically different and inferior. ${ }^{58}$ According to this model, the disabled individual's problem lies in the impairment. ${ }^{59}$ Consequently, the best way to help the disabled person is to use either medicine to cure or ameliorate the impairment, or rehabilitation techniques to enable the person to cope with or overcome the impairment's effects. ${ }^{60}$ Under the medical model, "society allocates to physicians the authority to validate the existence of the disability and thus to provide an individual with

53 See Scotch, supra note 3, at 214.

${ }^{54}$ Jonathan C. Drimmer, Cripples, Overcomers, and Civil Rights: Tracing the Evolution of Federal Legislation and Social Policy for People with Disabilities, 40 UCLA L. REV. 1341, 1345-46 (1993).

55 For example, the ADA appears to contain vestiges of the moral model as illegal drug use, 42 U.S.C. § 12210 (1994); homosexuality, bisexuality, and transvestitism, 42 U.S.C. § 12211(a)(b)(1) (1994); and compulsive gambling, kleptomania, or pyromania, (b)(2) are excluded from the definition of disabled.

${ }^{56} I d$. "This model assumed that the primary problem faced by people with disabilities was the incapacity to work and otherwise participate in society. It further assumed that such incapacity was the natural product of their impairments, and to some extent their own 'secondary' psychological reactions to their impairments." Scotch, supra note 3, at 214; see also Mary Crossley, The Disability Kaleidoscope, 74 NOTRE DAME L. REV. 621, 649 (1999) (defining medical model).

${ }_{57}$ Crossley supra note 56, at 649-50.

58 Id.

59 Id. at 650

${ }^{60} \mathrm{Id}$. 
access to whatever social assistance may be available to disabled persons." ${ }^{\prime 61}$

The economic model arose after the advent of World War $\mathrm{II}^{62}$ and views disability as a "phenomenon that lies at the intersection of human impairment and the market for labor." ${ }^{\prime 63}$ The economic model views disability as the limiting effect imposed on individuals' functional capacity and is assessed according to how much it restricts people from performing the primary or essential activities of their work. ${ }^{64}$ The economic model is intended to promote the economic self-sufficiency of individuals with disabilities by increasing their participation in compensated labor. ${ }^{65}$

In stark contrast to the medical model, the social model of disability sees disadvantages as flowing from social systems and structures. ${ }^{66} \mathrm{~A}$ major premise of this model is that disability is a social construct, rather than a biological phenomenon. ${ }^{67}$ Thus, the disadvantaged status of persons with disabilities is the product of a hostile or inhospitable social environment, not simply the product of bodily defects. ${ }^{68}$ Another important premise of the social model is that disability may also be a

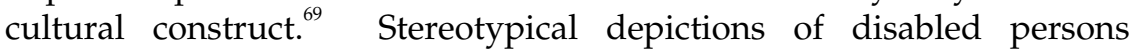
perpetuate social prejudices and bolster the non-disabled person's fear of disabled persons. ${ }^{70}$ Thus, the barriers embedded in social structures and attitudes also construct disability. ${ }^{71}$ A corollary of the belief that disability is a social construct is the view that normalcy itself is also a social construct. ${ }^{72}$

From the social model grew the civil rights model, based largely on the civil rights movement of the 1950s and 1960s. ${ }^{73}$ Under this model, the

1 Id.

62 Berg, supra note 11 , at 8 .

63 Id.

${ }^{64}$ Id.

65 Id.

${ }_{66}$ Crossley, supra note 56 , at 653.

67 Id. at 654

${ }^{68}$ Id. An example of how construction of physical environments can create disability is the construction of buildings with stairs, rather than elevators or ramps.

69 Id. at 655

${ }_{70}$ Id.

${ }^{71}$ Id. at 656.

${ }^{72}$ Id. The fundamental shortcoming of the social model is that by focusing on environmentally caused disadvantages; it ignores limitations inherent in bodily impairments.

${ }_{73}$ Drimmer, supra note 54, at 1355. 
legal and social status of disabled persons reflects underlying social attitudes and assumptions concerning disability. ${ }^{74}$ Above all, the civil rights model seeks to "unmask the false objectivity that allows society to label some of its members 'disabled' and treat those citizens as less than equal.",75 "In seeking appropriate remedies, the civil rights model adopts three goals from the civil rights movement of other minority groups.,"76 The first goal is to eradicate perceptions of inferiority and all other irrational reactions. ${ }^{77}$ The second goal is to eliminate discrimination that results from such prejudices. ${ }^{78}$ Finally, the model "pursues a 'level playing field,'" or equality of opportunity, by aggressively securing access to, and independence in, all aspects of society."

\section{The Present: Centrality of a Traditional Medical Model}

One distinct feature of disability is that it has been linked with concepts of health, disease, and illness in U.S. disability policy. As Paula Berg has observed, "the definition of disability in antidiscrimination law is part of a larger cultural discourse that establishes and upholds dominant notions of health, illness, and disability while imposing a particular set of expectations upon individuals deemed to occupy each class." ${ }^{80}$

Early disability-based welfare programs medicalized disability, defining it as an exclusively individual and clinical concept. ${ }^{81}$ The ADA is generally thought to embody the social and civil rights models of disability. ${ }^{82}$ However, "[d] espite the civil rights intent of this bill, and the

${ }^{74} \quad$ Id.

${ }^{75}$ Id. at $1355-56$.

${ }^{76}$ Id. at 1358.

77 Id.

78 Id.

79 Id. at 1358.

80 Berg, supra note 11, at 4.

81 See, e.g., DEBORAH A. STONE, THE DisAbled StATE (1984) (the disability category as an administrative category in the welfare state, and use of medical certification as the core administrative mechanism for defining the disability category).

${ }^{82}$ See Tucker, Revolving Door, supra note 52, at 340 ("[ $\left.\mathrm{t}\right]$ he ADA purports to be a civil rights law; it was premised on the concept of civil rights for individuals with disabilities"); Matthew Diller, Judicial Backlash, the ADA and the Civil Rights Model, 21 BERKELEY. J. EMP. \& LAB. L. 19, 31 (2000) ("[t]he ADA explicitly adopts a civil rights approach to the problems that people with disabilities encounter in the workplace"); Matthew Diller, Dissonant Disability Policies: The Tension Between the Americans with Disabilities Act and Federal Disability Benefit Programs, 76 TEX. L. REV. 1003, 1005 (1998) ("[t]he ADA is premised on the recognition that barriers to full participation are socially created, rather than the inevitable consequence of medical impairments. It establishes the principle that the inclusion of 
findings and purposes which recognize widespread discrimination, the medical and social pathology treatment of disability is seemingly inescapable. ${ }^{\prime 83}$ Indeed, current ADA jurisprudence suggests a recommitment to a narrow and individualistic biomedical model as the primary understanding of disability. ${ }^{84}$ In each of the recent trilogy of ADA cases on standing, Sutton v. United Airlines, ${ }^{85}$ Murphy v. UPS, ${ }^{86}$ and Albertson's v. Kirkingburg, ${ }^{87}$ the Supreme Court focused on the objective, biomedical nature of the plaintiffs' alleged impairments, and whether or not they represented a substantial personal loss of capacities. ${ }^{88}$ The Court's restrictive category of disability "reflects and reinforces the notion that disability is an objective biomedical phenomenon that constitutes an essential aspect of the individual. ${ }^{\prime{ }^{89}}$

Disability also remains undertheorized, in particular the integration of health-related and socially-created or -constructed aspects of disability. ${ }^{90}$ These two aspects are not necessarily in conflict - we recognize that "impairment is not 'natural,' but a historically changing category" without denying its materiality. ${ }^{91}$ Even assuming that disability is largely socially-created or -constructed, we know little about the nature of disability apart from those social forces. In other words, "[a]fter the

people with disabilities into all aspects of society is a civil right.").

83 Drimmer, supra note 54, at 1399.

${ }^{84}$ See, e.g., Berg, supra note 11, at 13 ("[d] espite its centrality to anti-discrimination law, courts largely eschewed the socio-political perspective when determining whether a plaintiff claiming discrimination is disabled and therefore entitled to legal protection. Instead, they have remained firmly entrenched in an essentialist biomedical understanding of disability, which has resulted in the fabrication of an extremely narrow category of disability").

85527 U.S. 471 (1999).

86527 U.S. 516 (1999).

87527 U.S. 555 (1999).

${ }_{88}$ There is also evidence that the court's analysis of the "regarded as" disabled cases also demonstrates a return to a traditional medical model of disability. Berg asserts that, in these cases, courts have improperly grafted the actual disability analysis - whether plaintiff's impairment substantially limits one or more of his major life activities - onto the "regarded as" prong. In other words, courts have held that to be "regarded as" disabled within the meaning of the ADA, the defendant must falsely perceive that the impairment substantially limits one or more of the plaintiff's major life functions. Simply demonstrating that the defendant discriminated on the basis of a real or imagined physical or mental impairment, even when plaintiff's condition is widely stigmatized, is insufficient to prevail. Berg, supra note 11, at 1.

${ }^{89}$ Id. at 4.

${ }^{90}$ Francis \& Silvers, supra note 5, at xxiv.

${ }_{91}$ Jerome E. Bickenbach et al., Models of Disablement, Universalism and the International Classification of Impairments, Disabilities and Handicaps, 48 SOC. SCI. \& MED. 1173, 1177 (1999). 
social causes of disadvantage are accounted for, what is left? ${ }^{\prime 92}$ Consequently, this Article takes a fresh look at the medical literature and its application to developing a theory of disability.

\section{B. Re-examining the Medical Literature: Two Views of Health}

Despite the uncompromising character of the traditional medical model of disability, theories of health, illness, and disease in the medical literature have alternated between two divergent perspectives, a functional model and an experiential model. ${ }^{93}$ This debate is significant because it resonates with the underlying question of whether disability is "a feature of the individual - a biological or medical personal limitation - or a feature of society - a social limitation imposed on people in virtue of their physical or mental differences." ${ }^{\prime 94}$

\section{Functional Health and the Traditional Medical Model of Disability}

The dominant paradigm of health in modern medicine is a biomedical model that incorporates a theory of functional determinism. ${ }^{95}$ The work of American philosopher Christopher Boorse provides the most clear and influential explanation of that model. ${ }^{96}$

According to Boorse, a healthy body is one in which every organ makes at least its species-typical contribution to the goals of survival and

92 Ron Amundson, Biological Normality and the ADA, in AMERICANS WITH DISABILITIES 102-03 (2000).

${ }_{93}$ Consider the two definitions of health found in the Oxford English Dictionary: "soundness of body; that condition in which its functions are duly and efficiently discharged" and "spiritual, moral, or mental soundness or well-being." OXFORD ENGLISH Dictionary. See also Robert A. AROnOWitz, M.D., MAKING SENSE Of Illness: SCIENCE, SOCIETY AND DISEASE 8 (1998) ("these ideal typical notions have been in a state of dynamic tension since antiquity").

${ }^{94}$ Introduction: Definitions: Who is Disabled? Who is Protected?, in AMERICANS WITH DISABILITIES 87 (2000).

95 Indeed, even critics of a functional determinism approach to health concede that "the dominant model of disease today is biomedical, with molecular biology as its basic scientific discipline. It assumes disease to be fully accounted for by deviations from the norm of measurably biological (somatic) variables. It leaves no room within its framework for the social, psychological, and behavioral dimensions of illness." George L. Engel, The Need for a New Medical Model: A Challenge for Biomedicine, SCIENCE, Apr. 8, 1977, at 129, reprinted in GEORGE L. ENGEL, FAMILy SYSTEM MEDiCINE 318-19 (1992). See also Roberto Moradacci, Health as an Analogical Concept, 20 J. MED. \& PHIL. 475, 479 (1995).

${ }_{96}$ The following discussion is based on two of Boorse's main works on the subject, On the Distinction Between Disease and Illness, 5 PHIL. \& PUB. AFF. 49-68 (1975) [hereinafter Boorse, Distinction] and Health as a Theoretical Concept, 44 PHIL. OF SCI. 542-73 (1977), as well as a more recent response to criticisms of his theory, A Rebuttal on Health, in WHAT IS DiseASE 3, 6-16 (James M. Humber \& Robert F. Almeder, eds., Humana Press 1987). 
reproduction. Disease is a state that interferes with or prevents normal functioning, defined as species-typical contribution to those goals. Health, then, is simply the lack of disease, a state in which all of an individual's bodily or mental functions fall within a normal functional range. Boorse assumes a notion of normal or natural function, which can be objectively established by empirically observed biostatistical norms. Accordingly, health and disease are individualized, biologically determined, and objectively measurable states. In contrast, illness is a subset of disease with normative aspects, and not purely a biostatistical phenomenon like health and disease. According to Boorse, a person is ill if and only if the person has a disease which is serious enough to be incapacitating, and therefore is 1) undesirable to its bearer, 2) a title to special treatment, and 3) a valid excuse for normally criticizable behavior. $^{97}$

Boorse's theory of health as an objectively measurable state of functional normality continues to be influential in medicine and medical ethics. In a 1981 address to the Association of American Physicians, then president Dr. Donald W. Seldin asserted that medicine is "a very narrow discipline," with three necessary features, "biomedical science as the underlying basis of medical theory and knowledge, its use for the mitigation of specifically biomedical derangements (pain, disability, premature death), and its application to the individual human being." ${ }^{\prime 98}$ He received a standing ovation. ${ }^{99}$ More recently, Norman Daniels has argued that the preservation and restoration of normal function is a primary goal of health care, citing Boorse as the authority on the objectivity of normal function: "[T] he kinds of [health care] needs picked out by reference to normal species functioning are objectively important because they meet this high-order interest persons have in maintaining a normal range of opportunities. ${ }^{\prime 100}$ Indeed, Boorse's influence can be seen in the prevalence of functional assessment - evaluation of the patient's ability to carry out the basic activities of living commonly defined as eating, turning over in bed, using the toilet, moving from place to place, walking, dressing, and taking care of personal hygiene - as a measure

97 Boorse, Distinction, supra note 96, at 61.

98 Donald W. Seldin, Presidential Address: The Boundaries of Medicine, reprinted in THE SOCIAL MEDICINE READER 244, 251 (Gail E. Henderson et al., eds. 1997).

99 Reported by Gerald T. Perkoff, The Boundaries of Medicine, in THE SOCIAL MEDICINE READER 254-52.

100 Norman Daniels, Justice and Health Care, in HeAlth CARE ETHICS: AN INTRODUCTION 290, 301 (Donald Van DeVeer \& Tom Regan eds., 1987). 
of health. ${ }^{101}$

The influence of Boorse's theory of health as a personalized and objectively measurable state of functional normality can also be seen in the traditional medical model of disability. Disability appears as a "chronic functional incapacity whose consequence was functional limitations assumed to result from physical or mental impairment,",102 and a person with a disability appears biologically abnormal and inferior. ${ }^{103}$ Clinical measurement and verification of disability, ${ }^{104}$ as well as the development of an index to evaluate function according to the ability to perform tasks, are central to the traditional medical model. ${ }^{105}$

This influence can be seen in recent Supreme Court decisions relating to the ADA. In Toyota Motor Manufacturing v. Williams, ${ }^{106}$ the Court found that an employee with carpal tunnel syndrome, tendonitis, and other acknowledged impairments was not disabled within the meaning of the ADA because her impairments did not significantly affect her activities of daily life - such as the ability to "brush her teeth, wash her face, bathe, tend her flower garden, fix breakfast, do laundry, and pick up around the house" - but merely affected the specific tasks of her job. $^{107}$ Similarly, in Albertsons v. Kirkenburg ${ }^{108}$ the Court upheld Albertson's failure to rehire a driver with monocular vision because he did not meet the Department of Transportation's basic vision standards (even though he obtained a waiver of the standards under an experimental program). The Court focused on specific activities of daily living and found that although monocular vision is a physical

${ }^{101}$ Of course, functional assessment could be expanded to include aspects of psychosocial functioning, including cognition, behavior, and participation in social activities, or instrumental activities of daily living defined as cooking, shopping, using the telephone, doing laundry, managing medication, doing ordinary work around the house and using transportation. See Naoki Ikegami, Functional Assessment and Its Place in Health Care, 332 NEw ENG. J. MED. 598-99 (1995), available at http:/ / www.nejm.org/content/1995 /0332/0009/0598.asp.

102 Scotch, supra note 3, at 214 . This model assumed that the primary problem faced by people with disabilities was the incapacity to work and otherwise participate in society. It further assumed that such incapacity was the natural product of their impairments, and to some extent their own "secondary psychological reactions to their impairments." Crossley, supra note 56, at 649 .

${ }_{103}$ See Scotch, supra note 3, at 214; Crossley, supra note 56, at 649.

104 See STONE, supra note 81.

105 Donald L. Patrick, et al., Toward an Operational Definition of Health, 14 J. OF HEALTH AND SOC. BEHAV., 6 (1973).

106534 U.S. 184 (2002).

107 Id. at 184 .

108527 U.S. 555 (1999). 
impairment within the meaning of the ADA, it did not in this case amount to a disability because, in light of petitioner's natural compensation mechanisms, it did not substantially limit his major life activities, including the major life activity of seeing.

Interestingly, despite the placement of the physician as the verifying gatekeeper, in many contexts other than recent ADA decisions, the definition of disability is linked to the person's ability to perform his or her job. In other words, disability is the medically verified inability to work. ${ }^{109}$ Accordingly, "[o]ur society has largely obfuscated the difficult choices raised by these issues by delegating the assessment of the functional impact of medical conditions to the medical profession. This delegation reflects an assumption that such inquiries are subject to scientific resolution and do not call for political choices."110

\section{Experiential Health and the Social Model of Disability}

Despite the present vitality of the functional model of health, there is a compelling alternative - the experiential model of health. The work of Swedish philosopher Lennart Nordenfelt provides the most clear and influential explanation of this model. ${ }^{111}$

According to Nordenfelt, the experiential model of health is based on human welfare, defined as the ability of individuals to reach their vital goals, rather than statistical considerations. ${ }^{112}$ Health is defined in terms of "freedom from illness, the capacity for human development and selfdiscovery, and the transcendence of alienating social circumstances." ${ }^{113} \mathrm{~A}$ well-known example of the experiential model is the World Health Organization's definition of health as "the state of complete physical, mental, and social well-being and not merely the absence of disease or infirmity." ${ }^{114}$

109 See 42 U.S.C. $\S 423(\mathrm{~d})(1)$ (1994); Deborah Kaplan, The Definition of Disability: Perspective of the Disability Community, 3 J. OF HEAlth CARE L. \& POL'Y 352, 354 (2000).

${ }_{110}$ Matthew Diller, Entitlement and Exclusion: The Role of Disability in the Social Welfare System, 44 UCLA L. ReV. 361, 387 (1996) cited in Lars Noah, Pigeonholing Illness: Medical Diagnosis as a Legal Construct, 50 HASTINGS L.J. 241, 282 (1999).

${ }_{111}$ Lennart Nordenfelt, Concepts of Health and Their Consequences for Health Care, 14 THEORETICAL MED. 277, 279 (1993).

${ }_{112}$ Id. at $279-81$.

113 Sander Kelman, The Social Nature of the Definition Problem in Health, 5 INT'L J. OF HEALTH SERVICES 625, 629 (1987).

114 World Health Organization: Basic Documents, 26th Ed., World Health Organization, Geneva 1976. 
The experiential model of health departs from the functional model in a number of ways particularly relevant to disability. The experiential model of health rejects an objective, biostatistical concept of "normal." It critiques any definition of the goal of medicine as the preservation and restoration of normalcy, because such a goal presumes that normality is real, natural, and legitimate. ${ }^{115}$ For example, philosopher Ron Amundson has written that "to call a typical or average species member 'normal' is to assume a blueprint in the developmental process that simply does not exist" from a Darwinian perspective. ${ }^{116}$ Free from a purely descriptivist and statistical definition of normalcy, the experiential model of health can take into account variation based on environment and mechanisms of compensation.

Rather than simply focusing on the parts and functions of the individual, an experiential model suggests that inquiry should begin with consideration of the well being of the individual as a whole, and then proceed to a consideration of the parts of the human organism and their various functions. ${ }^{117}$ It rejects making the impairment, pathology, or disease primary.

The experiential model of health entails viewing human beings as active creatures living within a network of social relations. Proponents of the experiential model vigorously denounce the "disentaglement of the organic elements of disease from the psychosocial elements of human malfunction."118 They reject an ontological, biomedical concept of disease that assumes that "there exists some unadulterated biological core that is the real disease and that this biological core is frequently obscured and distorted by beliefs and attitudes."119 Instead, health and illness are defined as social experiences occurring in the context of culture: ${ }^{120}$

115 Amundson, supra note 92, at 104-05.

116 Id.

117 LENNART NORDENFELT, ON THE NATURE OF HEALTH: ACTION-THEORETIC APPROACH (1987); Nordenfelt, supra note 111, at 277-86; Lennart Nordenfelt, On the Relevance and Importance of a Notion of Disease, 14 THEORETICAL MED., 15 (1993) [hereinafter Nordenfelt, Relevance].

118 Engel, supra note 95, at 318: (citing RF Illustrated 3, 5 (1976)).

119 ARONOWITZ, supra note 93, at 171.

120 NORDENFELT, supra note 117, at 92; see also Leon Eisenberg, The Subjective in Medicine, 27 Perspectives IN Biology \& MED. 48 (1983). “To provide a basis for understanding the determinants of disease and arriving at rational treatments and patterns of health care, a medical model must also take into account, the patient, the social context in which he lives, and the complementary system devised by society to deal with the disruptive effects of illness, that is, the physician role and the health care system." Engel, supra note 95, at 324. 
Physicians diagnose and treat diseases, which are thought of as entities independent of subjectivity, manifest in abnormalities in bodily structure and function. In this view, a disease is the same wherever in the world it occurs, whatever beliefs may be held regarding its genesis or cure, and whomever it affects; by definition, its pathology can be verified by agreed upon "objective" methods. Yet even casual familiarity with the history of medicine indicates just how mutable and dynamic disease constructs are. ${ }^{121}$

Indeed, as Robert A. Aronowitz writes in Making Sense of Illness, "consensus about illness is usually reached as a result of negotiations among the different parties with a stake in the outcome. Insights from the clinic and laboratory create options for a new disease or a different meaning of an existing name, but do not ultimately determine the outcome of a largely social process of negotiation."122

The experiential model also recognizes the subjective or value-laden nature of health. It challenges the functional model's distinction between disease - conceptualized as an objective pathology - and illness conceptualized as a subjective, social experience. Instead, it posits disease pathology as mutable and dynamic. ${ }^{123}$ As one proponent accurately observes, "[t]he boundaries between health and disease, between well and sick, are far from clear and never will be clear, for they are diffused by cultural, social, and psychological considerations." ${ }^{124}$ As a result, the experiential model has room for the genuine discrepancy between illness as actually experienced by the patient, and as conceptualized by the biomedical model. Nordenfelt observes that "[m]any bodily and mental states which are intuitively considered to be diseases or signs of ill health, need not involve any statistical abnormal function" and conversely, that given certain environments, "a certain reduction of function can in fact be the statistically normal one." ${ }^{125}$ For example, tooth decay is considered a pathology to be treated, but is sufficiently prevalent to be considered a statistical norm. Thus, although not totally subjective, "[w]hen individuals experience discomfort and dysfunction, they can be considered 'ill' only when such manifestations are recognized as illnesses according to community standards." ${ }^{126}$

${ }^{121}$ Eisenberg, supra note 120, at 54.

122 ARONOWITZ, supra note 93, at 1.

${ }^{123}$ Eisenberg, supra note 120, at 54.

124 Engel, supra note 95, at 332-33.

125 Nordenfelt, supra note 111, at 279.

126 "Neither disease nor illness are infinitely malleable both are constrained by biology and by culture." Nordenfelt, Relevance, supra note 117, at 59 . 
The experiential theory of health resonates strongly with the view that disability is subjective, flexible, and profoundly contextual. Even a cursory review of the literature on disability reveals that definitions vary according to time, place, and culture. ${ }^{127}$ One well known example is Nora Ellen Groce's study of hereditary deafness on Martha's Vineyard. ${ }^{128}$ A community on the island experienced a high incidence of hereditary deafness over a 200-year period. In response, in addition to spoken English, all members, both hearing and deaf, knew and used an early form of sign language to communicate. Groce found that in this bilingual community, deaf community members enjoyed equality in childhood, education, marriage, making a living, economic success, town affairs, legal responsibility, social life, and community life. Indeed, she notes that community members, both hearing and deaf, did not consider deafness to be a disability - "[t]hey were just like everyone else... [e]veryone here spoke sign language." ${ }^{\prime 29}$ The deaf did not feel stigmatized until summer people arrived and branded them "primitives" or "retarded." ${ }^{\prime 130}$ Groce concludes that disability is a socially constructed category, and that "[t]he Martha's Vineyard experience suggests strongly that the concept of a handicap is an arbitrary social category. And if it is a question of definition, rather than a universal given, perhaps it can be redefined, and many of the cultural preconceptions summarized in the term 'handicapped' as it is now used,

${ }^{127}$ For example, the SSDI benefits program defines disability as:

(A) Inability to engage in any substantial gainful activity by reason of any medically determinable physical or mental impairment which can be expected to result in death or which has lasted or can be expected to last for a continuous period of not less than 12 months; (2) For purposes of paragraph (1)(A) - An individual shall be determined to be under a disability only if his physical or mental impairment or impairments are of such severity that he is not only unable to do his previous work but cannot, considering his age, education, and work experience, engage in any other kind of substantial gainful work which exists in the national economy, regardless of whether such work exists in the immediate area in which he lives, or whether a specific job vacancy exists for him, or whether he would be hired if he applied for work. For purposes of the preceding sentence (with respect to any individual) "work which exists in the national economy" means work which exists in significant numbers either in the region where such individual lives or in several regions of the country.

42 U.S.C. § 432(d)(1)(1994).

${ }^{128}$ Nora Ellen Groce, Everyone Here SPOKe Sign Language (Harvard Univ. Press 1985).

${ }^{129} \mathrm{Id}$. at 2 .

${ }^{130}$ Id. at 95. 
eliminated." ${ }^{131}$

The social construction of disability sees "nonbiological factors beliefs, economic relationships, societal institutions - as greatly influencing, if not defining, our understanding of [disability]." ${ }^{132}$ This echoes the insights of Feminist and Critical Race scholars. Feminist scholars, for example, noted that "as the twentieth century began, the inferior status and attenuated social participation of women and people of color were portrayed as being natural consequences of their differences in talent and character." ${ }^{\prime 33}$ They also exposed the ways in which "medical discourses have historically constituted a site of sexual discrimination, using medic-scientific justification for differentiating women from men on the basis of biology and anatomy and to provide 'scientific evidence' to prevent women from entering public life." ${ }^{134}$ As it relates to disability, "[t]he social constructionist approach does not necessarily call into question the reality of disease or illness states or bodily experiences, it merely emphasizes that these states and experiences are known and interpreted via social activity and therefore should be examined using cultural and social analysis." ${ }^{135}$

\section{Debating Distribution: ReAsonable AcCommodation AND COSTS}

A second, related reason for inconsistent outcomes is an ambivalent attitude toward the costs of antidiscrimination law, often expressed as a tension between the languages of efficiency and of rights. In the context of disability-based discrimination in the workplace, this ambivalence is evident in the "deep tension between the view of disability discrimination as a civil rights problem, and the view of disability

131 Id. at 108

${ }^{132}$ ARONOWITZ, supra note 93, at 57. In addition to its relationship to an experiential theory of health, social constructionism is linked to the emergence of poststructuralism, second-wave feminism and Foucauldian scholarship. DEBORAH LUPTON, MEDICINE AS CUlture: IlLNESS, DISEASE AND THE BODY IN WESTERN SOCIETIES 11 (1994) (social constructionism is not new, but "the growing predominance of poststructuralist analyses of issues surrounding concepts of reality and bodily experiences in the humanities and social sciences has given renewed vigor and intellectual interest in its application to the area of the sociology of health and illness after a long period of marginalization.")

133 Anita Silvers, Formal Justice, in DISABILITY, DIFFERENCE, DISCRIMINATION: PERSPECTIVES ON JUSTICE IN BIOETHICS AND PUBLIC POLICY 15 (Anita Silvers et al. eds., 1998) [hereinafter Silvers, Formal Justice].

134 LUPTON, supra note 132 , at 131.

135 Id. at 11. 
discrimination as a social safety net issue."136 Although arguably both efficiency and rights may provide a basis for legislation such as the $\mathrm{ADA}^{137}$ the tension between them bears close examination in light of the tight relation between the construction of disability and the nature of disability rights.

\section{A. The Language of Efficiency and the ADA}

\section{Neoclassical Economic Model}

The language of efficiency is exemplified by the neoclassical economic model of the labor market. Simply stated, the goal of the neoclassical economic model of the labor market is to "achieve legal regimes whose efficiency mirrors those attained in an ideal market of perfectly competitive equilibrium." ${ }^{\prime 138}$ Of course, efficiency has a special meaning, typically wealth-maximizing or at least wealth-enhancing. For example, a Pareto model of efficiency provides that a distribution is efficiency enhancing if it increases aggregate wealth and also increases the wealth of all parties to it. In contrast, the more utilitarian Kaldor-Hicks formulation provides that a distribution is efficient if it generates aggregate benefits that exceed the total losses imposed, so that the winners could, in theory, compensate the losers so that no individual would be worse off than they were prior to the distribution and at least one person would be better off. In the ADA context, an efficiency analysis might begin by comparing employer costs of reasonable accommodation to the employee benefits of reasonable accommodation. $^{139}$

136 Francis \& Silvers, supra note 5, at XV.

137 See C. Edwin Baker, Utility and Rights: Two Justifications for State Action Increasing Equality, 84 YALE L.J. 39, 48 (1975).

138 Michael Ashley Stein, Labor, Markets, Rationality and Workers with Disabilities, 21 Berkeley J. Emp. \& Lab. L. 314, 314 (2000). This article was a major source of inspiration for this section, as it examines and critiques the application of the neoclassical labor market, as defined by Professor Epstein and his supporters, to Title I of the ADA. In particular, it identifies the three main justifications of Professor Epstein as discussed below, and analyzes four faulty assumptions underlying the justifications: over-reliance on the rationality of the market model, inaccurate assessment of the productivity of workers with disabilities, inappropriate weighing of co-worker and client "distaste" for workers with disabilities, and omission of significant benefits of employees with disabilities.

139 See, e.g., Douglas A. Leslie, Accommodating the Disabled, www.legalessays.com (1999). 
According to the neoclassical economic model, antidiscrimination statutes are inefficient and unnecessary. ${ }^{140}$ For example, Richard Epstein argues that prejudice against people with disabilities is rational and efficient, and the ADA is inherently inefficient. ${ }^{141}$ Professor Epstein's argument that the costs of reasonable accommodation outweigh its potential benefits rests principally on three grounds for believing that the potential benefits associated with reasonable accommodation of workers with disabilities are inherently less than the costs they engender: people with disabilities are inherently less productive than people without disabilities; providing reasonable accommodation is always costly to the employer; and providing reasonable accommodation incurs the social cost of coworkers' awkward and unpleasant feelings. Therefore, requiring employers to hire people with disabilities when they would otherwise choose not to requires those employers to bear costs. ${ }^{142}$

Moreover, Epstein and his adherents argue, the costs to employers of complying with the ADA greatly outweigh the benefits provided to people with disabilities. ${ }^{143}$ In the words of one economic critic, "[ $\left.t\right]$ he central flaw of the ADA is in the imposition on employers of a duty to accommodate the mental or physical limitations of the disabled worker or applicant without weighing the expected benefits of such accommodation... This, in combination with the antidiscrimination provision, distorts a civil rights measure into what is essentially a mandated benefits program for the disabled." ${ }^{144}$

\section{Critique of the Neoclassical Economic Model}

The common critiques of the neoclassical economic model and its application to antidiscrimination law fall along two lines: the model is internally flawed because it relies upon incorrect assumptions and incomplete data, and the model is inherently flawed because it inappropriately subjects everything, including rights, to a cost-benefit analysis.

${ }_{140}$ Michael Ashley Stein, Labor Markets, Rationality and Workers with Disabilities, 21 BERKELEY J. EMP. \& LAB. L. 314 (2000).

${ }_{141}$ See RICHARD EPSTEIN, FORBIDDEN GROUNDS (1992); Richard Epstein, Two Conceptions of Civil Rights, 8 SOC. PHIL. \& POL'Y J. 38 (1991).

142 See Stein, supra note 138, at 317.

143 See, e.g., Christopher J. Willis, Title I of the Americans with Disabilities Act: Disabling the Disabled, 25 CuMB. L. REV. 715 (1995).

144 Carolyn L. Weaver, Incentives versus Controls in Federal Disability Policy, in DISABILITY AND WORK: INCENTIVES: RIGHTS AND OPPORTUNITIES 5 (Carolyn L. Weaver, ed. 1991). 
As to the first line of critique, the central assumption of the neoclassical economic model is that the market is rational. ${ }^{145}$ However, many have persuasively argued a set of theories to explain the persistence of group-based employment discrimination - to satisfy a personal preference or "taste" for discrimination, ${ }^{146}$ to achieve higher status within the group, ${ }^{147}$ or to minimize the cost of employee diversity and divisiveness. ${ }^{148}$ Specifically, disability can evoke irrational behavior that is not inherently different than parallel historical responses by the dominant majority to the exclusion of other groups. ${ }^{149}$

As to the second line of critique, there is substantial empirical evidence refuting the valuation of costs and benefits in the context of employment of people with disabilities. As noted above, an efficiency analysis would compare employer costs of reasonable accommodation to the employee benefits of reasonable accommodation. As to the employer costs, people with disabilities are not inherently less productive. Even prior to the ADA, studies indicated that employees with disabilities demonstrate good to excellent work performance, no increase in insurance costs, lower turnover than workers without disabilities, lower rates of absenteeism, and lower rates of accident. ${ }^{150}$ Nor is providing reasonable accommodation always costly. Although the size of the financial burden on employers as a result of the reasonable accommodation requirement is not clear, a review of the available data suggests that the majority of accommodations cost less than $\$ 100$ per employee. ${ }^{151}$ Indeed, after a

145 A second faulty assumption is that efficiency can be measured in some objective manner. As noted by Duncan Kennedy more than 20 years ago, efficiency is an indeterminate concept, and there is no agreement as to how externalities can be measured from the setting of entitlement. Duncan Kennedy, Cost-Benefit Analysis of Entitlement Problems: A Critique, 33 STAN. L. ReV. 387 (1981).

146 GARY BECKER, THE ECONOMICS OF DISCRIMINATION 14 (3d ed. 1971).

${ }_{147}$ Richard H. McAdams, Cooperation and Conflict: The Economics of Group Status Production and Race Discrimination, 108 HARV. L. REV. 1003 (1995).

148 EPSTEIN, supra note 140.

149 Stein, supra note 138, at 314. Here, too, the data is incomplete. Blanck \& Marti, supra note 49, at 359 ("Study is lacking on the relationship between employer attitudes and behavior toward disability, and biases inherent in the purported qualifications required to perform jobs."); id. at 367 ("Another area worthy of study is the relation of employers' organizational cultures to employment and work benefit decisions involving qualified job applicants with hidden and perceived disabilities.").

${ }_{150}$ The March-April Issue of In the Mainstream reviewed 11 studies related to the employment of persons with disabilities and the results were consistent among all studies from 1948-1990.

${ }^{151}$ A 1994 report from the President's Committee on Employment of People with Disabilities found that since October 1992, 68\% of the accommodations made for workers with disabilities cost $\$ 500$ or less. See Epstein, supra note 25, at 394 n.11. "Materials in the 
review of the available data, one author concludes:

From an economic perspective, although the direct costs of the accommodations for any particular disability tend to be low, many companies regularly make informal and undocumented accommodations that require minor and cost-free workplace adjustments that are implemented directly by employees and their supervisors. For qualified employees whose conditions are asymptomatic or controlled by medication, any such necessary accommodations are typically minimal. Moreover, accommodations involving universally designed and advanced technology have been shown to enable groups of employees with and without disabilities to perform jobs productively, costeffectively, and safely. These findings suggested that the direct costs of accommodations may be lower than predicted. ${ }^{152}$

As to the employee benefit, it is difficult to measure the value of reasonable accommodation to the employee. ${ }^{153}$ Moreover, the structure of the comparison overlooks the benefits to the employer. As noted by Michael Ashley Stein, such benefits may include: savings in recruitment, training, and replacement expenses; higher productivity; greater dedication, fewer insurance claims, a reduction of post-injury rehabilitation costs, and more widespread use of available technologies; public costs savings, including reduction of disability-related public assistance obligations estimated at $\$ 120$ billion annually; and intangible benefits such as permitting people with disabilities to exercise all the responsibilities of citizenship.

\footnotetext{
ADA's legislative history indicate costs to businesses for reasonable accommodations are expected to be less than $\$ 100$ per worker for 30\% of workers needing an accommodation, with $51 \%$ of those needing an accommodation requiring no expense at all." S. REP. NO. 116, (1989). A study commissioned by Sears, Roebuck, and Co. indicated that $69 \%$ of the reasonable accommodations provided by the company cost nothing, $28 \%$ cost less than $\$ 1,000$, and only $3 \%$ cost more than $\$ 1,000$. Moreover, the average cost to Sears of providing workplace accommodations to employees with disabilities was less than $\$ 50$, compared with an average cost of $\$ 1,800$ and $\$ 2,400$ for terminating and replacing an employee, respectively. See Blanck, supra note 25, at 283. A 1982 Department of Labor study found only $22 \%$ of individuals with disabilities received any form of accommodation under the Rehabilitation Act, and of that group 51\% of the accommodations imposed no costs and 30\% imposed a cost of less than $\$ 500$ per worker. See Tucker, supra note 25 , at 930.

152 Blanck \& Marti, supra note 49, at 379-80.

${ }_{153}$ Gregory Crespi, Efficiency Rejected: Evaluating "Undue Hardship" Claims Under the Americans with Disabilities Act, 26 TULSA L.J. 1 (1990).

154 Stein, supra note 138, at 326-27. See also Blanck \& Marti, supra note 49, at 377-81; PETER DAVID BLANCK, Studying Disability, Employment Policy and the ADA, in AMERICANS
} 
Others argue that even if these foundational assumptions and valuations were corrected, the neoclassical economic model would still be inherently flawed because it inappropriately subjects everything, including significant rights, to a cost-benefit analysis. According to the neoclassical economic model, if the ADA's reasonable accommodation provision is characterized as at least partially intended to enhance efficiency by correcting market failures, ${ }^{155}$ then where the cost of accommodation exceeds its benefits, the employer should be able to invoke the undue hardship defense and avoid making the accommodation, because otherwise an inefficient activity will take place and will reduce total wealth.

However, authors such as Gregory Crespi have forcefully argued that this principally economic interpretation of the ADA is incorrect and inappropriate:

The language of the statute, its legislative history, and the inapplicability in the disability employment accommodation context of the key premises underlying the economic efficiency orientation all indicate that little if any weight should be given to efficiency considerations in determining the availability of the undue hardship defense for ADA-covered employers. ${ }^{156}$

\section{B. The Language of Rights and the ADA}

As the quote above suggests, the language of rights is an alternative to the language of efficiency. ${ }^{157}$ In political theory, rights have been understood as a serious entitlement that people have to some liberty, service, or good, derived from social rules and institutional roles. Once a right is recognized, it can be guaranteed through a legal enactment and legally enforced through law. Rights are not subject to utilitarian

WITH DisABILITIES 209, 212-14 (2000) (citing study commissioned by Sears, Roebuck, and Co. that indicated the average costs to Sears for terminating and replacing an employee was $\$ 1,800$ and $\$ 2,400$, respectively). Another benefit may be a reduction of the labor market costs of churning and scarring. See J. Hoult Verkerke, An Economic Defense of Disability Discrimination Law at http:/ / papers.ssrn.com/paper.taf?abstract_id=170014.

155 Crespi, supra note 151, at 6-7.

156 Id.; see also Rebecca Hanner White, Deference and Disability Discrimination, 99 MicH. L. REV. 532 (2000) (arguing jurisprudential and policy considerations strongly favor judicial deference to the EEOC's interpretation of the ADA).

${ }_{157}$ Although rights are the subject of deep skepticism on the left, the possibility that rights are valuable, not only as a means in the political struggle, but as ends in themselves, has not been totally abandoned. See generally Anthony Chase, The Left on Rights: An Introduction 62 TEX. L. REV. 1541 (1984). 
analysis. As Ronald Dworkin has argued, "a right is a claim which the government would be wrong to override if the government's only grounds were that overriding the right would increase the well being of the community as a whole. Thus, a right is a claim to have a certain need satisfied even if having this need satisfied causes a decrease in total or average utility." ${ }^{158}$

\section{Negative and Positive Rights}

Rights can be classified in different ways. One of the most influential classifications, and the one most relevant to an examination of attitudes toward disability-based discrimination, is Isaiah Berlin's concept of positive and negative liberties. ${ }^{159}$ Briefly stated, a negative right is freedom from interference. Classic examples of negative rights include fundamental freedoms such as freedom of speech, religious tolerance, and freedom from arbitrary arrest. A positive right is a freedom to act in a positive way, which entails the provision by some individual or institution of a valued service. Thus, positive rights require the state to act positively to promote the well being of its citizens, rather than merely refraining from interfering.

Modern courts accept the negative rights model in Constitutional interpretation, and civil rights laws are generally interpreted as declarations of negative liberty. ${ }^{160}$ However, classification of the ADA has been controversial because disability law and policy has traditionally been framed as positive entitlements to benefits or services, designed to assist those who are presumed to be dependent and not self-sufficient. ${ }^{161}$ To paraphrase two disability scholars, it is one thing to repeal the ordinances that require certain kinds of people to use the back door, but quite another to require the construction of ramps, instead of or in addition to stairs, up to the door. ${ }^{162}$ As one author has noted, "[c]laiming

158 Baker, supra note 137 , at 48.

159 See generally Isaiah Berlin, Two Concepts of Liberty, in FOUR ESSAYS ON LIBERTY 118 (Oxford 1969).

160 See, e.g., David P. Currie, Positive and Negative Constitutional Rights, 53 U. CHI. L. REV. 864 (1986); Susan Bandes, The Negative Constitution: A Critique, 88 MICH. L. REV. 2271 (1990).

161 See, e.g., IDEA, 20 U.S.C. \$§ 1401-1485 (1994 \& Supp. IV 1998); Developmental Disabilities Bill of Rights Act of 1975, amended by 42 U.S.C. \$§ 6000-83 (1994); Air Carrier Access Act of 1986, 49 U.S.C. § 41705 (1994); Voting Accessibility for the Elderly and Handicapped Act of 1984, 42 U.S.C. 1973ee (1994); Sections 501 and 503 of the Rehabilitation Act of 1973, 29 U.S.C. §§ 791-797(b)(f) (1994 \& Supp. III 1997); Fair Housing Act Amendments of 1988 (FHAA), 42 U.S.C. §§ 3601-3631 (1994 \& Supp III. 1997).

162 Francis \& Silvers, supra note 5, at xvii. 
a right to needs-based allocation generates powerful normative dissonance, because where political rights are implicated, people expect allocations to be based on the principle of equality, under which everyone is treated the same." ${ }^{163}$ Consider, for example, the passionate public responses to golfer Casey Martin's suit against the PGA pursuant to the public accommodation title of the ADA: ${ }^{164}$

"Casey Martin has always known that the PGA Tour requires walking in order to compete, yet he feels he is special enough to warrant special consideration. How much more selfish can you get?"

$\ldots$

"So what if you have had to face some adversity or someone has died in your family? If you don't qualify for the competition, you simply don't play at that level .... [Q]uit contributing to this stupid theory that because someone can make you feel sorry for them they deserve different treatment. . Be a Man!',165

Some have argued that the ADA is a welcome change from traditional disability policy because it promotes negative rights. In particular, philosopher Anita Silvers asserts that the ADA simply requires the removal of barriers that make it more difficult for some than for others to have access to major means of achieving the good life, such as education,

${ }^{163}$ Linda Hamilton Krieger, Afterword: Socio-Legal Backlash, 21 BERKELEY. J. OF EMP. \& LAB. L. 476, 509 (2000). Walter Y. Oi, Disability and a Workfare-Welfare Dilemma, in DISABILITY AND WORK: INCENTIVES, RIGHTS AND OPPORTUNITIES 32 (Carolyn L. Weaver ed. 1991). ("the ADA undermines the goal of living independently; disabled people cannot have it both ways. They cannot achieve true independence by demanding equal job opportunities and equal access when the social costs of these rights are thrust upon the general public.").

164 PGA Tour Inc. v. Martin, 532 U.S. 661, 690 (2001) (holding that allowing disabled golfer use of golf cart was required by Title III of ADA, despite walking requirements that applied to association's tours).

165 Alan Shipnuck, Martin Ruling Still a Hot Topic, SPORTS IlLUSTRATED (June 6, 2001), available at http://sportsillustrated.cnn.com/inside_game/alan_shipnuck/news/2001/06 /11/on_tour/index.html. Compare the interview with Andrew Imparato, a disability activist with the American Association of People with Disabilities. CNN Access, Disability Activist on Martin Decision (May 29, 2001), available at http:/ / www.cnn.com/2001/law/05

/29/scotus.golfer.cnn/index.html ("We saw this case as not being about an unfair advantage or special treatment, but about all athletes having an opportunity to compete."). See also Cary LaCheen, Achy Breaky Pelvis, Lumber Lung and the Juggler's Despair: The Portrayal of the Americans with Disabilities Act on Television and Radio, 21 BERKELEY J. EMP. \& LAB. L. 223 (2000). 
employment, or health care. ${ }^{166}$ Because those barriers result from unfairly exclusionary or injurious practices, ${ }^{167}$ Silvers and others argue that the ADA merely corrects a market shaped by discrimination. ${ }^{168}$ In addition, the employment title promotes a traditional concept of equality of opportunity that merely limits the manner in which employers can treat employees. Silvers conceptualizes this as "formal justice," which "aims at reforming processes central to the achievement of moral connectedness so as to ensure their inclusiveness regardless of disability,"169 and "[o]ffers recourse to individuals when mistaken or misleading assumptions about disability weight commonplace practices against them." ${ }^{170}$ Thus, the ADA is not about special benefits or redistribution of material resources - a goal which would not address the systemic bias that disadvantages people with disabilities - but instead promotes access comparable to that of people without disabilities. ${ }^{171}$

More often, however, the ADA and its employment title are understood as conveying positive rights, as it requires that employers both refrain from discrimination and make affirmative reasonable accommodations. ${ }^{172}$ Significantly, the duty to reasonably accommodate is not merely corrective because it is not premised on a showing of past discrimination. As such, Title I's reasonable accommodation provision "appears to make a revolutionary break with the old ways of thinking about discrimination while charting a new course of affirmative obligations to ensure real equality."173

\section{Critique of the Negative-Positive Dichotomy}

The familiar critiques of the negative-positive dichotomy also fall along two lines. First, there are arguments about which category certain

166 Silvers, Formal Justice, supra note 133, at 13; Anita Silvers, (In)Equality, (Ab)Normality, and the Americans with Disabilities Act, 21 J. MED. AND PHIL. 209 (1996) [hereinafter Silvers, (In)Equality].

167 Silvers, Formal Justice, supra note 133, at 132.

${ }_{168}$ Richard J. Arneson, Disability, Discrimination and Priority, in AMERICANS WITH DISABILITIES 18 (2000).

169 Id. at 121.

170 Id. at 120 .

171 Silvers, Formal Justice, supra note 133, at 13; Silvers, (In)Equality, supra note 166, at 209.

172 David Wasserman, Distributive Justice, in DISABILITY, DIFFERENCE, DISCRIMINATION 147 (1998); see also Miranda Oshige McGowan, Reconsidering the Americans with Disabilities Act, 35 GA. L. REV. 27, 35 (2000).

173 McGowan, supra note 172 , at 35. 
rights fit into. For example, many have argued that there have always been both negative and positive rights within the Constitution. ${ }^{174}$ As David Currie notes, "[f]rom the beginning there have been cases in which the Supreme Court, sometimes very persuasively, has found in negatively phrased provisions constitutional duties that can in some sense be described as positive. ${ }^{175}$

Others challenge the dichotomy itself as false, ${ }^{176}$ as even classically conceived negative rights require some sort of government funding or state intervention. ${ }^{177}$ Building upon the insights of the legal realists "to the extent that rights enforcement depends upon judicial vigilance, rights cost, at a minimum, whatever it costs to recruit, train, supply, pay and (in turn) monitor the judicial custodians of our basic rights." ${ }^{178}$ As one scholar has remarked, "[l]eave me alone" is not a transcendent, contextfree right, but a "rhetorical front behind which the meaning, costs, and consequences of negative rights lie concealed."179 Certainly, there have been costs of eradicating discrimination in the workplace - shifting patterns and practices have always entailed costs. For example, Title IV's prohibition against sexual harassment in the workplace is "enforced through the not-inexpensive efforts of the EEOC and state employment agencies." ${ }^{\prime 180}$ Indeed, Title VII has provided women with a "positive right to a less offensive workplace." ${ }^{181}$ In this sense, the employment title of the ADA is not unique, just more overt. ${ }^{182}$

There are two possible consequences of this latter critique of the negative-positive dichotomy. A blurry or nonexistent boundary may justify further extension into the area of positive rights. Indeed, some

${ }_{174}$ Currie, supra note 160, at 864; Bandes, supra note 160, at 2271 (offering philosophical and common sources of conventional wisdom); Laurence H. Tribe, The Abortion Funding Conundrum: Inalienable Rights, Affirmative Duties, and the Dilemma of Dependence, 99 HARV. L. REV. 330 (1985).

175 Currie, supra note 160 , at 886.

${ }^{176}$ For a feminist critique of the foundations of both negative and positive liberty, see Diana Coole, Constructing and Deconstructing Liberty: A Feminist and Poststructuralist Analysis, XLI(1) POL. STUD. 83-95 (1993).

177 Aditi Gowri, Reproduction, Rights and Public Policy: A Framework for Assessment, 35 TEX. INT'L L.J. 13 (2000).

${ }_{178}$ Patricia Illingworth \& Wendy E. Parmet, Positively Disabled: The Relationship Between the Definition of Disability and Rights under the ADA, in AMERICANS WITH DISABILITES 6 (2000) (citing HOLMES \& SUNSTEIN, infra note 184 at 45). But see Tucker, supra note 52, at 336.

179 Gowri, supra note 177, at 18.

${ }_{180}$ Illingworth \& Parmet, supra note 178 , at 13.

${ }^{181} \mathrm{Id}$.

182 Id. See also Stein, supra note 139, at 314 (ADA does not radically depart from other civil rights statutes and reasonable accommodation is not uniquely expensive). 
have praised the ADA for its embodiment of both positive and negative rights - "The genius of the ADA is that it forthrightly melds positive and negative rights, creating a civil rights statute that goes beyond the simplistic equal-opportunity-as-negative-rights model represented by Title VII." ${ }^{183}$ The more troubling consequence is the subjection of all rights to a cost-benefit analysis. For example, Steven Holmes and Cass Sunstein assert that both the conservative and the liberal positions in the current debate unquestioningly accept the negative/positive distinction, and therefore either ignore the true cost of "rights" or reject all consideration of the costs of "rights," respectively. Instead, the scope of any right always demands a trade-off analysis that weighs the expected social costs of enforcing a particular right against those of those rights, legal entitlement, and public policy objectives. ${ }^{184}$

\section{BACK TO THE THREE FACES OF REASONABLE ACCOMMODATION}

As identified in Section I, despite a decade of litigation, there is no consistent understanding of the reasonable accommodation requirement. Indeed, there are three inconsistent distributive outcomes that appear to comport with the reasonable accommodation requirement: cost-shifting, cost-sharing, and cost-avoidance. Such disparate outcomes exist for two reasons: a failure to develop a coherent and consistent theory of disability, and an ambivalent attitude toward the costs of antidiscrimination law. Accordingly, using a theory of disability informed by an experiential definition of health and the associated distributive analysis developed in sections II and III, respectively, this section contextualizes and evaluates cost avoidance, cost sharing, and cost shifting.

\section{A. Cost Avoidance is an Unwelcome Return to the Past}

Cost avoidance, whereby ERISA-regulated disability benefits and the structure of ERISA's remedial scheme are used by employers to avoid,

183 Illingworth \& Parmet, supra note 178, at 8.

184 STEPHEN HOLMES \& CASS R. SUNSTEIN, THE COST OF RIGHTS: WHY LIBERTY DEPENDS ON TAXES (W.W. Norton 1999). Both the conservative and the liberal positions in the current debate unquestioningly accept the negative/positive distinction, and therefore either ignore the true cost of "rights" or reject all consideration of the costs of "rights," respectively. Instead, the scope of any right always demands a trade-off analysis that weighs the expected social costs of enforcing a particular right against those of those rights, legal entitlement and public policy objective. For a review and criticism, see generally Jonathan M. Barnett, Rights, Costs, and the Incommensurability Problem, 86 VA. L. REV. 1303 (2000). 
consciously or unconsciously, the duty of reasonable accommodation of employees with disabilities, returns to a strong medical-functional model of disability and operates as a modern form of safety net for those deemed unfit for the self-defined workplace.

\section{A Strong Medical-Functional Model of Disability}

The cost avoidance outcome is strongly linked with the traditional medical model of disability and the functional model of health. The worker with a disability is seen as biologically abnormal, inferior, and unfit for the demands of the workplace. The emphasis on individual biological function and impairment to the exclusion of environmental context makes the unemployment of people with disabilities appear as a "simple fact of nature" rather than a social phenomenon. ${ }^{185}$

Cost avoidance also places the (seemingly) objective science of medicine at the center of the process, as most plans require a worker to submit sufficient objective medical evidence of his or her disability as part of the benefits application process. ${ }^{186}$ Clinical measurement and verification of disability, and particularly the use of indexes to evaluate function according to the ability to perform tasks, are prevalent. ${ }^{187}$ Individual physicians serve "to validate the existence of the disability and therefore provide an individual with access to whatever social assistance may be available to disabled persons..188 Despite the use of physicians as gatekeepers, the definition of disability is frequently keyed to the person's ability to perform his or her job. In other words, disability is the medically verified inability to work. ${ }^{189}$ Insistence upon individual, clinical verification medicalizes, and therefore depoliticizes, the social causes of disability. ${ }^{190}$

185 Amundson, supra note 92, at 105.

186 See cases cited, supra note 38.

187 See cases cited, supra note 38; Vlas v. Raythem Employees Disability Trust, 244 F.3d 27 (1st Cir. 2001); Goad v. Lockheed Martin Energy Systems, Inc., 8 Fed. Appx. 524, 2001 WL 493403 (6th Cir. 2001); Heller v. Fortis Benefits Ins. Co., 142 F.3d 487 (D.C. Cir. 1998); see also, Patrick et al., supra note 105.

188 Crossley, supra note 56, at 650.

189 See 42 U.S.C. § 423(d)(1) (1994); Kaplan, supra note 109, at 354.

190 Lupton, supra note 132, at 108 ("doctors are called upon to make authoritative judgments for the legal system, employers and other social authorities; for example, when examining an employee for superannuating purposes or sick leave certification, or when assessing the extent of disability of the disabled, or when pronouncing death. Doctors have the power to certify whether a person is physically able to work or not, and to decide when a patient should return to work. This doctor-patient interaction may reinforce the definition of health as the ability to work, for 'the healthy person is the person who 
From the perspective of a former worker with a disability, "[b]eing seen as the object of medical treatment evokes the image of many ascribed traits, such as weakness, helplessness, dependency, regressiveness, abnormality of appearance, and depreciation of every mode of physical and mental functioning." ${ }^{\prime 191}$ It may also require him or her to assume the sick role, which excuses the individual from the normal obligations of society, including going to work. ${ }^{192}$ According to American sociologist Talcott Parsons, "ill persons are exempted from the performance of social obligations which they are normally expected to fulfill, they are not blamed for their condition, and they need not feel guilty when they do not fulfill their normal obligations; however, ill people must want to try and get well - if they do not, they can be accused of malingering; and being sick is defined as being in need of medical help to return to 'normality' - the sick must put themselves into the hands of medical practitioners to help them get well again." ${ }^{193}$

The emphasis on the disability and the assumption of the sick role may also trigger the spoiling process, whereby the physical impairment obscures all other characteristics behind the one and swallows up the social identity of the individual within that restrictive category. ${ }^{194}$

\section{Special Distributions for Unsuitable Workers}

Because disability is seen as a personal misfortune, a private and voluntary remedy such as cost avoidance appears appropriate. ERISA does not require that employers provide disability benefits or provide any minimum benefits or eligibility standards. No employee with a disability has a right to insist that his employer provide disability benefits, although many employers choose to do so. Moreover, any benefits or assistance that the employer chooses to offer are subject to the terms of the plan drafted and agreed upon by the employer and the insurance company, if any.

The cost-avoidance outcome deems disability a legitimate excuse from economic self-sufficiency, and provides disability benefits as a safety net. The cost avoidance model looks a lot like traditional U.S. disability

produces.'”). See also Berg, supra note 11, at 44 ("[a] practice of determining disability on an individualized basis undermines a sustained political consciousness among people with disabilities, and, in turn, undermines a unified disability rights movement.").

191 Irving Kenneth Zola, Self, Identity, and the Naming Question: Reflection on the Language of Disability, in THE SOCIAL MEDICINE READER 77, 79 (Gail E. Henderson et al. eds, 1997).

${ }^{192}$ Kaplan, supra note 109, at 353-54.

193 Lupton, supra note 132, at 7.

194 Zola, supra note 191, at 79. 
policy, such as the Social Security Disability Insurance and Supplemental Security Income Benefits ("SSDIB") program, which guarantees a subsistence income to persons with total, long-term disabilities. ${ }^{195}$ Neither of these traditional programs nor the cost-avoidance outcome offers individuals enough money to participate fully in the life of the community, or the status and satisfaction that come from economic selfsufficiency. ${ }^{196}$

The construction of the disability benefits also strongly suggests that employees with disabilities either "overcome" their limitations in order to meet the non-negotiable demands of the workplace, or remain permanently unemployed. The worker with a disability is seen as simply unable to work and unsuitable for the work environment. Instead of examining environmental barriers, the best way to help the disabled person is to use either medicine to cure or ameliorate the impairment, or rehabilitation techniques to enable the person to cope with or overcome the impairment's effects. "The primary thrusts of social policy regarding disability are both to eliminate as much disability as possible, by using medical technology to cure existing disability or prevent future disability, and to use rehabilitative techniques to help disabled individuals approximate dominant physical standards as closely as possible." ${ }^{197}$ The two-tiered definition of disability common to many plans suggests that disability from your "own occupation" should be temporary - the former employee on disability leave is encouraged to overcome the disability through medical care, ${ }^{198}$ to seek medical care to heal or "adapt themselves to the demands of productivity set in the marketplace." ${ }^{199}$ After expiration of that period, the worker will either return to his occupation, ${ }^{200}$ retrain for another suitable occupation, or

${ }_{195}$ See 42 U.S.C. $\S 423$ (1994) (SSDIB), 42 U.S.C. § 1382 (SSI) (1994).

196 See David E. Bernstein, Roots of the Underclass: The Decline of Laissez-Faire Jurisprudence and the Rise of Racist Labor Legislation, 43 AM. U. L. REV. 85, 119-36 (1993), for the position that welfare programs tend to trap individuals in a low-income underclass, and are therefore less desirable than measures that lead to integration into the workforce.

${ }_{197}$ Crossley, supra note 56 , at 652.

198 And, an employee is often required to have continuous medical care to continue to receive benefits. See, e.g., Lown v. Continental Cas. Co., 238 F.3d 543, 549 (4th Cir. 2001) (defining total disability as "continuously unable to perform the substantial and material duties of his regular occupation ... and under the regular care of a licensed physician other than himself").

199 See Scotch, supra note 3, at 219.

200 At least one court has held that even an involuntary return to work for financial reasons disqualifies an employee from receiving disability benefits. Galman v. The Prudential Ins. Co. of Am., 2001 U.S. App. LEXIS 15415 (8th Cir. June 28, 2001). In that case, the court rejected plaintiff 's argument that such a bright-line test created an incentive 
remain unemployed and continue to collect available benefits.

By focusing on adaptations required from people with disabilities, the cost-avoidance outcome requires very little from employers beyond establishment of a disability benefits plan. It does not incorporate any concept of reasonable accommodation or any other form of environmental alteration. ${ }^{201}$ Thus, private employers continue to define work and "normal" workplace standards. ${ }^{202}$ There is no recognition of the disability category as a political and nonneutral instrument of the employer to control the workforce. ${ }^{203}$ Consider Professor Susan Wendell's personal example of disabling workplace rulemaking:

I am currently just able (by doing very little else) to work as a professor three-quarter time, on one-quarter disability leave. There has been much talk recently about possible increases in the teaching duties of professors at my university, which would not be accompanied by any reduction in expectations for the other two components of our jobs, research and administration. If there were to be such an increase in the pace of professors' work, say by one additional course per term, I would be unable to work more than half-time (by the new standards) and would have to request halftime disability leave, even though there had been no changes in my physical condition. Compared to my colleagues, I would be more work-disabled than I am now. Some professors with less physical limitation than I have, who now work full-time, might be unable to work at the new full-time pace and be forced to go on part-time disability leave. This sort of change could contribute to disabling anyone in any job. ${ }^{204}$

Or consider an example from a recent Supreme Court case, Toyota Motor Manufacturing $v$. Williams. ${ }^{205}$ Ms. Williams began working at an automobile manufacturing plant in 1990 on the engine fabrication assembly line. When use of the pneumatic tools on the assembly line caused pain in her hands, wrists, and arms, diagnosed as bilateral carpal

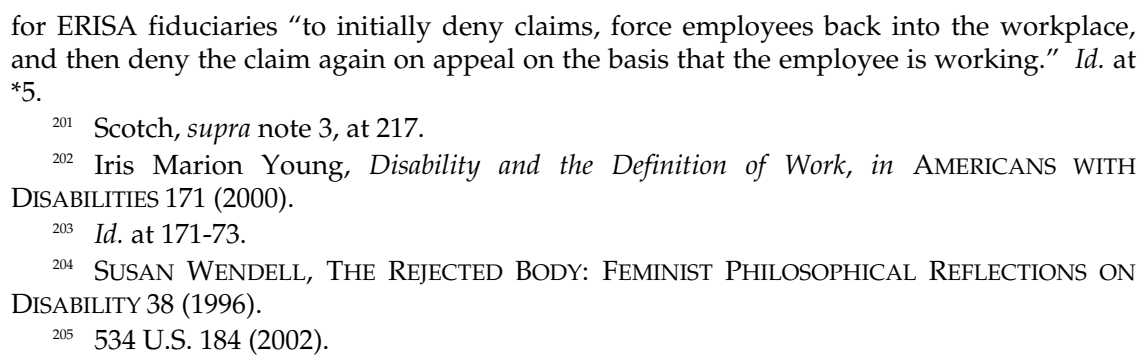


tunnel syndrome and bilateral tendonitis, she was transferred to modified duty jobs. In 1993, she was transferred to a paint and body inspection line, which required visual and manual inspection tasks. In light of her medical restrictions, she performed only the visual inspection for several years without incident. However, in 1996, her employer instituted a new requirement that all paint and body inspection line employees perform both visual and manual inspection, and she once again began to experience pain in her neck and shoulders that interfered with her ability to perform her job. Thus, Ms. Williams was transformed from adequate worker to inadequate worker by virtue of her employer's policy change in 1996.

In the realm of disability policy, the idea that rules can disable is not new. In fact, one early definition of the word "disabled" is "incapacity recognized or created by law; legal disqualification." ${ }^{\prime 26}$ To disable a person is to disqualify legally, to pronounce legally incapable. The "disabling" of employees who could perform the essential function of their jobs with reasonable accommodation is particularly disturbing because people with disabilities want to work. A survey cited in the legislative history of the ADA reports that a large majority of the twothirds of working age persons with disabilities who do not have jobs say that they want to work and $82 \%$ of people with disabilities said they would give up their government benefits in favor of a full-time job. ${ }^{207} \mathrm{~A}$ more recent survey by the Harris polling organization reported that of persons who identified themselves as having disabilities who were not working and were ages 16 to $64,79 \%$ said that they would prefer to be working. ${ }^{208}$

Finally, the cost-avoidance outcome is incompatible with the stated purpose of the ADA "to provide a clear and comprehensive national mandate to end discrimination against individuals with disabilities" and "to bring those individuals into the economic and social mainstream of American life." ${ }^{209}$ Instead, it looks like a private, voluntary form of the traditional U.S. policy toward people with disabilities, the creation of a

\footnotetext{
${ }^{206}$ NEW SHORTER OXFORD ENGLISH DictionARY 682 (Leslie Brown ed., Clarendon Press 1993)

${ }^{207}$ H. R. Rep. No. 101-485 (II), pt. 2, at 32 (1990) (citing the ICD Survey of Disabled Americans: Bringing Disabled Americans into the Mainstream 47-50), reprinted in 1990 U.S.C.C.A.N. 303, 314.

${ }^{208}$ LOUIS HARRIS \& ASSOCS., N.O.D./HARRIS SURVEY OF AMERICANS WITH DISABILITIES 55 (1994). A recent survey in a large state found that $72 \%$ of persons with disabilities who are unemployed want to work. Minette McGhee, Justice is Blind-for One Day: Court Gets Lesson on Disability, CHI. SUN TIMES, Nov. 19, 1992, at 22.

20942 U.S.C. $\$ 12101-12213$ (Supp. V 1990).
} 
public entitlement program such as SSDIB, that trades inclusion in the workplace for cash benefits. In contrast to the ADA, the alternate statutory structure into which workers are diverted, ERISA, is clearly not a civil rights statue, nor is its sole aim to protect workers. ${ }^{210}$ Indeed, it strips the plaintiff of civil rights protections and offers very little procedural or substantive protection in return. Thus, the practical result of the cost avoidance outcome for people with disabilities - exclusion, isolation, and economic dependence - is the very problem that the ADA seeks to remedy.

\section{B. Cost-Sharing is an Uncertain Bargain}

Cost-sharing, whereby the structure of reasonable accommodation and undue hardship creates a zone of bargaining in which the minimum the individual with a disability is willing to accept is less than the maximum the employer is willing to offer, is linked to a weaker medical-functional model of disability and offers only the possibility of a privately negotiated remedy.

\section{A Weak Medical-Functional Model of Disability}

As with the cost-avoidance outcome, the worker with a disability is seen as biologically abnormal and inferior and potentially unfit for the workplace. However, the consequence of the impairment is subject to negotiation. There is at least the possibility of focusing on environmental issues, such as changes to the workplace, in addition to the individual biological functioning and impairment, but certainly no guarantees.

It is not clear whether the cost-sharing model appoints the physician as gatekeeper, as individual employers may or may not require objective medical evidence or ongoing medical care. However, the definition of disability would still be keyed to the individual's ability to perform her job, as defined by the employer.

\section{Bargaining for Benefits}

As with the cost-avoidance outcome, the cost-sharing outcome recognizes that certain types of impairments can lead to social and economic isolation. However, because disability is seen as a personal

${ }_{210}$ See, e.g., Erik Nelson, Comment, A Poststructural Analysis of the Power and Class Behind the Formalist Application of ERISA Preemption of State Law, 11 ST. THOMAS L. REV. 175 (1998). 
misfortune, a private and voluntary contractual remedy appears appropriate. Again, employees with a disability do not have a right to insist that their employers bargain with them over accommodations, although the structure of the incentives within the ADA may influence employers' decisions to do so. ${ }^{211}$ Moreover, any benefits or assistance that the employers choose to offer are subjected to the terms of the negotiated agreement.

Cost sharing preserves, to the extent possible, the freedom of the employer and the employee to bargain and to reach a mutually satisfying agreement. Because both parties have a direct interest in the outcome, cost sharing may focus more on the specific needs and desires of the parties and provide an opportunity for a quick, economical, and creative resolution. Evidence suggests that the vast majority of ADA disputes arise in cases in which the employee is already working for the employer, ${ }^{212}$ and the cost-sharing outcome may be particularly useful for such employees. It seems logical that an employee with a satisfactory employment relationship would be most likely to request and receive accommodations that would allow him or her to continue employment.

Although cost sharing may result in some accommodation of people with disabilities, according to Karlan and Rutherglen, the zone of bargaining operates to decrease costs of accommodations, thus lessening the impact of the property transfer. ${ }^{213}$ This may be exacerbated by the fact that the potential plaintiff faces a substantial risk in the courts. As disability scholar Ruth Colker has documented, appellate court decisions in ADA cases have been overwhelmingly pro-defendant since the ADA became effective. $^{214}$ Thus the end result is likely distributions to individuals with disabilities that are less than they are entitled to under the ADA.

${ }^{211}$ See Burkhauser, supra note 30, at 79 ("When a pathology begins to affect the ability to work, important job related decisions must be made by both worker and employer. These decisions may also be influenced by government policies. The worker will consider the relative rewards of continued work versus applying for transfer benefits. In like manner, the social institutions and legal mandates within which the firm must operate will influence an employer's willingness to accommodate the worker.").

${ }_{212}$ See John J. Donahue III \& Peter Siegelman, The Changing Nature of Employment Discrimination Litigation, 43 STAN L. REV. 983, 984 (1991); Mudrick, supra note 23, at 70, cited in Scotch, supra note 3, at 220.

213 See Karlan \& Rutherglen, supra note 27, at 30.

${ }^{214}$ Ruth Colker, The Americans with Disabilities Act: A Windfall for Defendants, 34 HARV. C.R-C.L. L. REV. 99, 101 (1999). 
As with cost avoidance, cost sharing is problematic for those antidiscrimination theorists who advocate a civil rights strategy. ${ }^{215}$ Agreements are reached informally by private, interested actors, without procedural protections or the public forum of the federal courts. Use of this process may result in a diminished ability to identify and resolve systemic, disability-based discrimination. ${ }^{216}$ There is also no assurance that employers will share their power to define work and acceptable workplace standards, ${ }^{217}$ nor is there necessarily a recognition of the disability category as a political and nonneutral instrument of the employer to control the workforce. Although cost sharing has potential, it appears to minimize any material redistribution as well as the opportunity for cultural transformation.

\section{Though Flawed, Cost Shifting is the Best Outcome}

Cost shifting, whereby employers meet their obligation to provide reasonable accommodation to make it possible for people with disabilities to perform essential job functions and to secure equal enjoyment of all terms and conditions of employers, faces significant obstacles to implementation. Nonetheless, it is the best outcome because it embodies a experiential-social model of disability and the potential for both socioeconomic and political reconstruction.

\section{A Potentially Strong Experiential-Social Model of Disability}

Cost shifting shares strong links to a experiential-social model of disability, which characterizes disability as subjective, flexible, and profoundly contextual. The experiential-social model of disability rejects making the impairment, pathology, or disease primary. In this sense, a person with a disability need not be defined by that disability or experience a spoiling of identity. ${ }^{218}$ There is a great deal of empirical

215 Karlan \& Rutherglen, supra note 27, at 4-5.

216 These concerns echo the analysis of mediation and the ADA. See Ann C. Hodges, Mediation and the Americans with Disabilities Act, 30 GA. L. REV. 431 (1996); see also 2000 H.R. 4593 (a bill to amend Title VII, the ADEA, the ADA, the VRA and the Civil Rights Act of 1991 to require the EEOC to mediate employee claims arising under those acts).

217 Young, supra note 202, at 171-73.

218 "An investigation of 145 physically disabled individuals found that, compared to non-disabled persons, those with impairments did not rate their lives as less happy or satisfying. The people with disabilities did, however, rate their lives as more difficult and likely to stay that way. Another study of 88 seriously physically restricted persons posed the question, 'If you were given one wish, would you wish that you were no longer disabled?' Only half said they would wish to remove their disability." Experiences of 
evidence that people with even serious disabilities report a quality of life averaging only slightly lower than that reported by nondisabled people. $^{219}$ For example, one study indicated that people with impairments rated their lives as more difficult, but not less happy or satisfying. Moreover, only half would use one wish to remove their disability. ${ }^{220}$ Interestingly, physicians in particular estimate the quality of life of their disabled patients to be much lower than do the patients themselves. ${ }^{221}$

The ADA provides that any impairment or inability must be viewed in the context of the interaction between societal realities and choices and the individual's disability, and not in the context of the individual's disability per se. In that sense, the ADA's explicit portrayal of disability as socially constructed embodies the experiential-social model. Both recognize that disability is a relational term, defined by individuals' relationship to their specific environment. Rather than simply an objective biological impairment, disability is an "uncorrected mismatch between an individual and her environment." ${ }^{\prime 22}$ Accordingly, the disadvantaged status of persons with disabilities is the product of a hostile or inhospitable social environment, not simply the product of bodily defects: ${ }^{223}$

[D]isability is socially constructed by such factors as social conditions that cause or fail to prevent damage to people's bodies; expectations of performance; the physical and social organization of societies on the basis of a young, non-disabled, "ideally shaped," healthy adult male paradigm of citizens; the failure or unwillingness to create ability among citizens who do not fit the paradigm; and cultural representations, failures of representation, and expectations. Much, but perhaps not all, of what can be socially constructed can be socially (and not just intellectually) deconstructed, given the means and the will. ${ }^{224}$

Deviance, Chronic Illness, and Disability, in THE Social Medicine ReAder, 76 (Gail E. Henderson et al., eds. 1997).

${ }_{219}$ Amundson, supra note 92, at 106.

220 Experiences of Deviance, supra note 218, at 76.

${ }^{221}$ Amundson, supra note 92, at 106; Harlan Hahn, Accommodation and the ADA: Unreasonable Bias or Biased Reasoning?, 21 BERKELEY J. EMP. \& LAB. L. 166 (2000).

222 Arneson, supra note 168 , at 28.

${ }^{223}$ See id. (using example of wealthy, talented, charming, legless person). An example of how construction of physical environments can create disability is the construction of buildings with stairs, rather than elevators or ramps.

224 WENDELL, supra note 204, at 45. 
The inequality visited upon persons with disabilities is rooted in social practices that bar them from demonstrating their competence, not their impairment, real or perceived. For example, from the perspective of people who use wheelchairs, "disablement is experienced not as the absence of walking but as the absence of access to bathrooms, theaters, transportation, the workplace, medical services, and educational programs - all those opportunities most other citizens expect to access. ${ }^{225}$ In the words of another author, "if a person in a wheelchair cannot get to the post office in her town because there is no ramp or elevator, a socio-political analysis will locate the problem in the design of the building, not in her legs." 226

\section{An Opportunity for Redistribution and Social Reconstruction}

Reasonable accommodation as cost shifting goes beyond distribution of material resources, but also encompasses changes to the social environment. In contrast to the medical-functional model, which seeks to rehabilitate the disabled person, the primary thrust of policy under the social model is to eliminate disability by "rehabilitating" the social constructs that serve to impose disadvantages on persons with impairments. ${ }^{227}$ It also recognizes and seeks to remedy the use of the disability category as a nonneutral instrument of the state and private employer to control the workforce.

This dual value of reasonable accommodation as cost shifting resonates with Nancy Fraser's concept of a "critical theory of recognition." ${ }^{228}$ Fraser, a political scientist, developed a concept of "bivalent collectivities" that suffer "both socioeconomic maldistribution and cultural misrecognition in forms where neither of these injustices is an indirect effect of the other, but where both are primary and cooriginal." ${ }^{229}$ For such collectivities, neither redistributive remedies addressing socioeconomic injustice nor recognition remedies addressing

225 Silvers, Formal Justice, supra note 133, at 74.

226 Bickenbach et. al, supra note 91, at 1174 .

${ }^{227}$ Crossley, supra note 56, at 658.

${ }^{228}$ Nancy Fraser, From Redistribution to Recognition? Dilemmas of Justice in a 'PostSocialist' Age, in FEMINISM AND POLITICS 431 (Anne Phillips ed., 1998).

${ }^{229}$ Id. Fraser explains, "[t]he remedy for economic injustice is political-economic restructuring of some sort. This might involve redistributing income, reorganizing the division of labour, subjecting investment to democratic decision-making, or transforming other basic economic structures.... The remedy for cultural injustice, in contrast, is some sort of cultural or symbolic change. This could involve upwardly revaluing disrespected identities and the cultural products of maligned groups." Id. at 434 . 
cultural or symbolic injustice alone will suffice. ${ }^{230}$

Finally, unlike cost avoidance and cost sharing, cost shifting occurs by operation of the ADA and takes an explicit civil rights approach to the issue of disability-based discrimination. The ADA prohibits impairment-based subordination, and promotes the view that disability is not an inherent biological trait, but a "condition that results from the interaction between some physical or mental characteristic labeled as impairment and the contingent decisions that have made physical and social structures inaccessible to people with that condition." ${ }^{231}$ Accordingly, the appropriate remedy is civil rights legislation to eliminate the attitudes and practices that exclude people with actual, past, or perceived impairments from opportunities to participate in public and private life. ${ }^{232}$

\section{Addressing the Obstacles}

Although supported in the history and language of the ADA, the experiential-social model of disability and reasonable accommodation as cost shifting face significant barriers to implementation. It is a potentially transformative law captured by inappropriate biomedical and efficiency analyses. However, the experiential-social model of disability and its distributive implications can be used to reconstruct reasonable accommodations flaws.

The most problematic barrier for the experiential-social model of disability is the Supreme Court's return to a narrower, biomedical model of disability. As noted above, in the Supreme Court's recent ADA cases on standing, Toyota Motor Manufacturing $v$. Williams, ${ }^{233}$ Sutton $v$. United Airlines, ${ }^{234}$ Murphy v. UPS, ${ }^{235}$ and Albertson's v. Kirkingburg, ${ }^{236}$ the Supreme Court focused on whether or not the plaintiffs' impairments severely damaged their capacity in everyday life, and not simply their capacity to perform their actual jobs. In the words of the Williams court, "[w]hen addressing the major life activity of performing manual tasks, the central inquiry must be whether the claimant is unable to perform the variety of

230 Id. at 431 . (2000).

231 Samuel R. Bagenstos, Subordination, Stigma, and Disability, 86 VA. L. REV. 398, 426

232 Id.

233534 U.S. 184,122 S. Ct. 681 (2002).

234527 U.S. 471 (1999).

235527 U.S. 516 (1999).

236527 U.S. 555 (1999). 
tasks central to most people's daily lives, not whether the claimant is unable to perform the tasks associated with her specific job." ${ }^{237}$ Such a restrictive category reduces the pool of eligible plaintiffs — "[t]he judiciary's insistence upon viewing disability as an essential, biomedical fact - and its resistance to adopting a social political perspective - has led to the construction of a highly restrictive category of disability that reserves the law's protection for the relatively few who fit the American disabled ideal - men and women who struggle to independence and self-support despite the most incapacitating of impairments." ${ }^{238}$ This has been a boon for defendants. ${ }^{239}$

Despite the civil rights language, the civil rights approach often appears an uncomfortable fit. ${ }^{240}$ It appears that the Court's acceptance of the "positive" aspect of ADA, the duty of reasonable accommodation, is premised upon a very narrow definition of disability. Conversely, the Court's relative acceptance of the "negative" aspects of the ADA, the duty to refrain from discrimination, results in significantly limited relief.

Many argue for a rejection of the dichotomy - "The underlying principle of the ADA is that people with a disability must be fully integrated into society - that we must recognize the potential of all members of society, disabled or not, even though it may cost money or impose some burdens upon covered entities to reach this objective ${ }^{\prime \prime 241}-$ however, this argument raises the risk that rights guaranteed by the ADA will be subject to a cost-benefit analysis. In fact, the reasonable accommodation analysis is being compromised by an economic and

${ }^{237}$ Williams, 122 S. Ct. at 693.

238 Berg, supra note 11 , at 49-50.

${ }^{239}$ A comprehensive study of 1,200 court decisions by the ABA's Commission on Mental and Physical Disability Law found that employers have prevailed in $92 \%$ of final judicial dispositions. See Study Finds Employers Win Most ADA Title I Judicial and Administrative Complaints, 22 MENTAL \& PHYSICAL DisABILITY L. REP. 403 (1998); see also John W. Parry, Highlights and Trends: Employment Decisions under ADA Title I Survey Update, 23 MENTAl \& PHYSICAl DisABILITY L. REP. 290, 294 (1999) (reporting that in 1998, employers increased their win rate to $94 \%$ ); Colker, supra note 214 , at 160 . For an exploration of reasons for the seeming pattern of negative results, see Matthew Diller, supra note 82, at 19. Paula Berg has analyzed its tremendous negative impact on the issue of standing, noting that the majority of recent ADA decisions are exclusively concerned with the issue of standing - whether plaintiff is "disabled" as defined by the statute - and the majority conclude that they are not. Berg, supra note 11, at 2.

240 "There are numerous cases in which judges have treated the ADA definition as though the purpose of the law is to provide a social benefit, rather than to protect an individual from discrimination." Kaplan, supra note 109, at 360-61, citing Van Sickle v. Automatic Data Processing Inc., 166 F.3d 1216 (6th Cir. 1998), and Gilday v. Mecosta County, 124 F.3d 760 (6th Cir. 1997).

${ }^{241}$ Tucker, Revolving Door, supra note 52, at 351. 
utilitarian analysis, in the form of the Court's interpretation of the undue burden test. The undue burden limitation severely limits the application of the reasonable accommodation requirement, ${ }^{242}$ and ultimately reflects business's vision of integration as costly and intrusive. ${ }^{243}$ As Crespi has argued, a Pareto model of efficiency provides that a distribution is efficiency enhancing if it increases aggregate wealth, and also increases the wealth of all parties to it - a standard that few, if any, legal rules can satisfy. In contrast, the more utilitarian Kaldor-Hicks formulation provides that a distribution is efficient if it generates aggregate benefits that exceed the total losses imposed, so that the winners could, in theory, compensate the losers so that no individual would be worse off than he or she was prior to the distribution and at least one person would be better off. However, Crespi observes, such a utilitarian approach is on very tenuous grounds, especially in the disability employment context, because "the allowance of a set of undue hardship defense claims which individually and collectively satisfy Kaldor-Hicks ... may well impose substantial losses upon some group of disabled persons." ${ }^{244}$ Thus, the distinction between rights and entitlement is eroded by subjecting both to cost analysis. "If interpretation of the ADA continues in this direction, it will increasingly function as a statute that balances limited opportunities against their perceived costs. ${ }^{245}$

\section{CONCLUSION}

Using a theory of disability informed by an experiential-social definition of health and the distributive analysis to evaluate the three distributive outcomes demonstrates that, although flawed, cost shifting is the best outcome because it embodies a truer model of disability and the potential for both socioeconomic and political reconstruction. The experiential-social model of disability and its distributive implications can be used to reconstruct reasonable accommodation flaws - the reinvigoration of a conservative medical-functional model within the definition of disability, and the encroachment of an economic-based efficiency analysis within the reasonable accommodation analysis.

\footnotetext{
${ }^{242}$ It also endorses the perpetrator's and not the victim's perspective. See, e.g., MARTHA MinOW, MAKING ALL THE DIFFERENCE: INCLUSION, EXCLUSION, AND AMERICAN LAW 167 (1990).

${ }^{243}$ Sue A. Krenek, Note, Beyond Reasonable Accommodation, 72 TEX. L. REV. 1969, 1973 (1994).

${ }^{244}$ Crespi, supra note 151, at 33.

${ }^{245}$ Francis \& Silvers, supra note 5, at xxiii.
} 
This reconstruction offers the opportunity for a transition in disability policy from a necessary but not sufficient social safety net to a more complex system grounded in a fuller and more positive theory of disability, and the recognition of the civil rights of people with disabilities. 